\title{
Comparison of IASI water vapour products over complex terrain with COPS campaign data
}

\author{
Guido Masiello $^{1, *}$, CARmine Serio $^{1}$, Thomas Deleporte $^{2}$, Hervé Herbin $^{3}$, PaOlo Di Girolamo ${ }^{1}$, \\ CÉDric Champollion ${ }^{4}$, ANDreas BehrendT ${ }^{5}$, Pierre Bosser ${ }^{6}$, Olivier Bock ${ }^{7}$, \\ VOLKER WulfMeYeR ${ }^{5}$, MATTHIEU POMMIER ${ }^{2}$ and CYRILle FlaMANT ${ }^{2}$ \\ ${ }^{1}$ Scuola di Ingegneria, Università degli Studi della Basilicata, Potenza, Italy \\ ${ }^{2}$ Laboratoire Atmosphères, Milieux, Observations Spatiales, CNRS-UPMC-UVSQ, Paris, France \\ ${ }^{3}$ Laboratoire d'Optique Atmosphérique, CNRS and Université des Sciences et Technologies de Lille, Lille, France \\ ${ }^{4}$ Géoscience Montpellier, CNRS and Université Montpellier II, Montpellier, France \\ ${ }^{5}$ Institut für Physik und Meteorologie, Universität Hohenheim, Stuttgart, Germany \\ ${ }^{6}$ ING, École Nationale des Sciences Géographiques, LAREG, Marne-la-Vallée, France \\ ${ }^{7}$ ING, LAREG, Université Diderot, Paris, France
}

(Manuscript received August 31, 2012; in revised form September 27, 2013; accepted October 9, 2013)

\begin{abstract}
In this work, we compare IASI-retrieved vertical water vapour profiles and related precipitable water over a complex region, namely the Rhine Valley area, during the pre-operational period of IASI exploitation (JuneAugust 2007). Both IASI water vapour mixing ratio profiles and integrated water vapour content are retrieved from L1C radiances spectra using two techniques and compared with water vapour related observations acquired during the Convective and Orographically-induced Precipitation Study (COPS) field campaign that took place in this area at that time (i.e. lidars, radiosoundings and a global positioning system - GPS - station network). This work addresses the issue of IASI vertical spatial resolution and its capability to detect twolayer water vapour structures such as those observed in a mountainous area and which play an important role in convective initiation or inhibition. We found that this capability mostly relies on the type of a-priori background vector (climatology or space-time colocated ECMWF analysis), which is used within the retrieval scheme. Systematic comparison of water vapour products derived from 71 IASI spectra confirms that IASI can retrieve water vapour amounts in $2 \mathrm{~km}$ width layers, in the lower troposphere, with an accuracy of approximately $10 \%$.
\end{abstract}

Keywords: Water vapor, Infrared Atmospheric Sounding Interferometer (IASI), Raman lidar, Differential Absorption Lidar (DIAL), Global Positioning System (GPS), remote sensing.

\section{Introduction}

High-quality water vapour and temperature observations are necessary to improve our understanding of the Earth's climate system, as well as to improve weather forecasts. Water vapour is not only the most important greenhouse gas in the atmosphere, but also plays a key role for the comprehension and prediction of most important weather processes from convective initiation, to the formation of clouds and precipitation, to the formation of severe storms. Deeper process understanding and better model representation require high quality water vapour observations featuring global coverage and a previously unachieved accuracy and resolution. Satellite remote sensing has a great potential to provide global coverage of water vapour measurements. Passive remote sensors in the infrared and the microwave regions have been used to retrieve water vapour since the early 1970s. The Advanced Very-High Resolution Radiometer (AVHRR,

*Corresponding author: Guido Masiello, Scuola di Ingegneria, Università degli Studi della Basilicata, Viale dell'Ateneo Lucano 10, 85100 Potenza, Italy, e-mail: guido.masiello@unibas.it versions 1-3), the High-Resolution Infrared Radiation Sounder (HIRS, versions 1-3) and the Microwave Sounding Unit (MSU), the latter being replaced by the Advanced Microwave Sounding Unit (AMSU) since 1998, have been operational on-board NOAA TIROS satellite series, with the last launch in 2004 (NOAA 18), while upgraded versions of the AVHRR and HIRS sensors are presently flying on-board the MetOp Satellites $1-3$. These three sensors, forming the TIROS Operational Vertical Sounder (TOVS) unit, are characterized by a limited accuracy and vertical resolution e.g. (CHÉDIN et al., 1993) which do not reach the required level of water vapour data quality needed for climate studies and have a limited impact in numerical weather prediction (NWP) models through data assimilation (GÉRARD et al., 2004). Conversely, the Infrared Atmospheric Sounding Interferometer (IASI), (HILTON et al., 2012), also carried on the MetOp satellite, is probably at date the most advanced instrument in space for remote characterization of atmospheric temperature and humidity. Marking a significant technological step forward, it provides water vapour and temperature profiles with 
much higher accuracy and resolution than previous satellite-borne instruments.

Previously, the potential of IASI measurements in comparison with active remote sensing from space using a differential absorption lidar (DIAL) was studied in WULFMEYER et al. (2005) using synthetic data and retrievals. Furthermore, the potential of a space borne DIAL was demonstrated in DI GIROLAMO et al. (2008).

The present paper is dedicated to a comparison of IASI water vapour products with measurements performed by a variety of sensors in the framework of the Convective and Orographically-induced Precipitation Study (COPS) (WULFMEYER et al., 2008, 2011b). The comparison effort involves measurements from the global positioning system (GPS, both in terms of column integrated water vapour and tomography-derived water vapour mixing ratio profiles), radiosondes and a variety of lidar systems deployed at the different so-called supersites.

The capability of in-situ sensors for the verification of spaceborne sensors has been studied extensively within the scope of WMO intercomparison campaigns (NASH et al., 2010 with further references). Generally, if the recommended corrections are applied, Vaisala RS92 soundings should have an rms error less than $10 \%$ in the troposphere. However, this does not remove errors by different sampling of air masses in space and time within respect to the IASI profiles, which makes comparisons with soundings very challenging. In contrast, active remote sensing techniques such as Raman lidar e.g., (TURNER et al., 2002) and differential absorption lidar (DIAL) (WULFMEYER and BÖSENBERG, 1998; BRUNEAU et al., 2001a,b; BEHRENDT et al., 2009) deliver vertical profiles with high temporal and spatial resolution and errors less than 5\% throughout the troposphere. This was confirmed during a variety of intercomparison campaigns in the US at the SGP site with the ARM program (REVERCOMB et al., 2003) during the IHOP-2002 campaign (BEHRENDT et al., 2007a,b) and recently during COPS (BHAWAR et al., 2011). This makes Raman lidar and DIAL excellent candidates for the verification of spaceborne sensors.

A large amount of measurement techniques and numerical simulations have been employed during the COPS campaign. For the objective of comparison with IASI water vapour products, we focused on a small part of this data, which consist of GPS measurements (both integrated water vapour columns and water vapour tomography-derived profiles), radiosoundings and lidar water vapour profiles. We used a colocation criterion for the lidar and radiosondes comparisons of +/- $90 \mathrm{~min}-$ utes on a spatial grid to ensure that enough comparisons with the IASI retrieved profiles can be carried out.

According to POUGATCHEV et al. (2009); CALBET et al. (2011), this time-space window may not be enough to ensure a layer-to-layer comparison between profiles in the sense that we need to assess the co-location error before performing any kind of evaluation of the IASI retrieval accuracy. However, the $\mathrm{H}_{2} \mathrm{O}$ profile shape (we mean single layer or two-layer structure) is not expected to change over these time-spatial scales (see, e.g. (GRIECO et al., 2007), which still allows us to address the issue of IASI vertical spatial resolution. In contrast, the GPS tomography profiles are calculated exactly at the position of the IASI observation.

Bearing this in mind, a first objective of this study is to compare the IASI water vapour profiles retrievals done at LATMOS (Laboratoire Atmosphères, Milieux, Observations Spatiales, Paris, France) and DIFA (Dipartimento di Ingegneria e Fisica dell'Ambiente, Universit'a degli Studi della Basilicata, Potenza, Italy) based on two techniques built around the optimal estimation method but which differ in several aspects (spectral range, a priori determination, retrieval strategy and so on).

A second objective is to compare the IASI retrievals with water vapour profiles obtained by high vertical spatial resolution techniques, which are based on lidar and radiosonde observations performed during the COPS campaign. The comparison is mostly intended to check the capability of IASI in resolving two-layer water vapour structures in the lower troposphere e.g. see (GRIECO et al., 2007). This capability is important for studying and better understanding the convection process, but is also interesting for assessing the potential use of IASI water vapour fields for the derivation of atmospheric motion vectors. Finally, total columns have also been compared for the LATMOS and DIFA retrievals techniques and with GPS total column measurements.

The paper is organized as follows. Section 2 is devoted to the description of data, techniques and methods. A brief overview of the COPS campaign is presented in section 2.1, while section 2.1.1 to 2.1.4 describe lidar and GPS systems used during the campaign. IASI data and related methods are shown in sections 2.2 to 2.2.2. Results are shown in section 3, while conclusions are drawn in section 4 .

\section{Data}

\subsection{COPS campaign overview}

The COPS international field campaign took place from 1 June to 31 August 2007 in a low-mountain area in southwestern Germany/eastern France covering the Vosges mountains, the Rhine valley and the Black Forest mountains $\left(6-11^{\circ} \mathrm{E}, 47-50^{\circ} \mathrm{N}\right.$, see Fig. 1) (WULFMEYER et al., 2008, 2011a,b). The main scientific goal of the COPS campaign was the identification of the physical processes responsible for the quantitative precipitation forecasting in low-mountain regions. During the 3-month long campaign, a large suite of state-of-the-art meteorological instrumentation was operated (WULFMEYER et al., 2011a; WULFMEYER and BEHRENDT, 2007).

This includes networks of in situ and remote-sensing systems such as GPS stations as well as a synergy of multi-wavelength passive and active remote-sensing instruments such as advanced radar and lidar systems. 


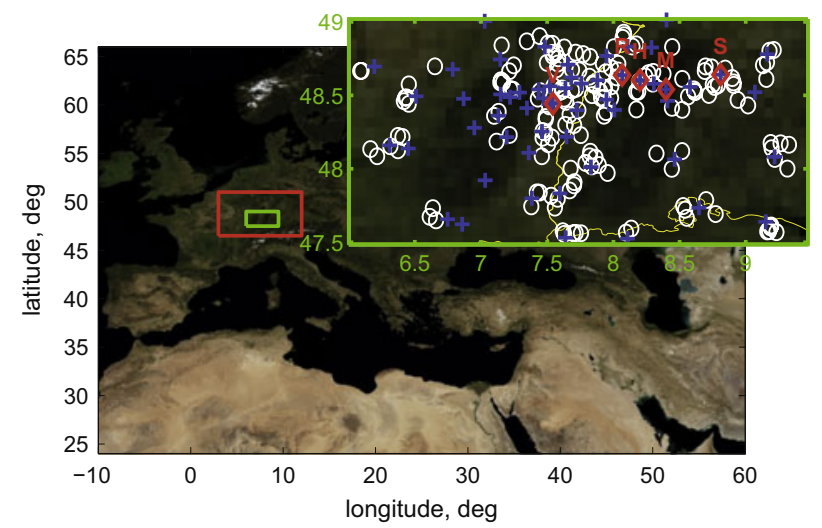

Figure 1: Map of the COPS campaign domain (green box). The red box is the domain used for a priori and climatology determination of the IASI retrievals at LATMOS. The zoomed panel shows the map of the COPS campaign domain. Red diamonds and blue crosses indicate respectively the 5 supersites and the positions of the GPS stations while the white circles represent the footprint positions of the 174 IASI spectra used in this work.

An impressive collection of instrumental set ups were concentrated in five so-called supersites along a westto-east transect (see Fig. 1) at the Vosges mountains (supersite V), Rhine valley (supersite R), Hornisgrinde mountain site (supersite $\mathrm{H}$ ), Murg valley (supersite $\mathrm{M}$ ) and Deckenpfronn close to Stuttgart (supersite S). The positions of these supersites are listed in Table 1.

During three months, 18 intensive observational periods totalling 37 days operation and eight additional special observational Periods were performed, providing a comprehensive dataset covering different forcing conditions. The collected data set covers the entire evolution of convective precipitation events in complex terrain from their initiation, to their development and mature phase until their decay. It is demonstrated that COPS research provided new insight into key processes leading to convection initiation and to the modification of precipitation by orography as well as in the improvement of quantitative precipitation forecasting by the assimilation of new observations (BAUER et al., 2011; BEHRENDT et al., 2011b; BIELLI et al., 2011; CORSMEIER et al., 2011; RICHARD et al., 2010; YAN et al., 2009), and in the performance of ensembles of convection-permitting models in complex terrain (BAUER et al., 2011).

\subsubsection{BASIL Raman lidar}

During COPS, the Raman Lidar system BASIL (UV BASIlicata Raman Lidar system at DIFA) was deployed in Achern (Rhine valley, Supersite R, Lat: $48.64{ }^{\circ} \mathrm{N}$, Long: $8.06{ }^{\circ} \mathrm{E}$, Elev.: $140 \mathrm{~m}$ ) and operated from 25 May to 30 August 2007, collecting more than 500 hours of measurements, distributed over 58 measurement days and 34 intensive observation periods. The major feature of BASIL is in its capability to perform high resolution and accurate measurements of atmospheric temperature and water vapour, both during the daytime and at nighttime, based on the application of the rotational and vibrational Raman lidar techniques in the UV spectral range (DI GIROLAMO et al., 2004, 2006, 2009a).

Besides temperature and water vapour, BASIL provides measurements of the particle backscattering coefficient at 355, 532 and $1064 \mathrm{~nm}$, the particle extinction coefficient at 355 and $532 \mathrm{~nm}$ and particle depolarization at 355 and $532 \mathrm{~nm}$. The experimental set-up of BASIL was described in various papers (DI GIROLAMO et al., 2009a,b; MAESTRI et al., 2010). Moreover, the Raman lidar technique for the determination of the water vapour mixing ratio profile has been extensively discussed in the literature (for a recent review, see (WHITEMAN, 2003)).

The water vapour mixing ratio can be obtained from the power ratio of water vapour to molecular nitrogen vibrational Raman signals. This ratio needs to be calibrated through an independent measurement, which is usually provided by radiosonde, GPS or microwave radiometer measurements. Specifically, during COPS the calibration was performed using an extensive comparison of the water vapour mixing ratio data from the lidar and simultaneous radiosondes (Vaisala RS92 radiosondes were considered for this purpose (BHAWAR et al., 2011).

Vertical and temporal resolution of BASIL raw data are 15-30 m and 5-60 sec, respectively. However, in order to reduce signal statistical fluctuations, time integration and vertical smoothing are applied to the data. For a time resolution of $10 \mathrm{~min}$ and a vertical resolution of $150 \mathrm{~m}$, nighttime water vapour mixing ratio measurement uncertainty is typically $2 \%$ at $4 \mathrm{~km}$ and $7 \%$ at $7 \mathrm{~km}$ (based on 13 distinct profiles used in 23 comparisons), while daytime uncertainty is typically $10 \%$ at $4 \mathrm{~km}$ and $20 \%$ at $5 \mathrm{~km}$ (based on 4 profiles used in 8 comparisons). Examples of measurements from BASIL during COPS are reported in Di GIROLAMO et al. (2012a,b); BENNETT et al. (2011); BEHRENDT et al. (2011b); KIEMLE et al. (2011).

\subsubsection{Rameau Raman lidar}

The Rameau lidar has been developed by the Institut National de l'Information Géographique et Forestière (IGN) in cooperation with the Laboratoire Atmosphères, Milieux, Observations Spatiales (CNRS-UPMC). It is equally referred to, in the text or figures, as the Rameau lidar or IGN/SA lidar. The system is intended to be operated in combination with GPS receivers to improve troposphere modelling (BOSSER et al., 2007). The Rameau lidar was operational during COPS at supersite $\mathrm{V}$ during the entire month of July 2007, for a total of about $200 \mathrm{~h}$ covering 25 measurement sessions. While the system was originally intended to operate both at night and in daytime, technical problems prevented it from performing precise daytime water vapour measurements, and observations were therefore limited to night-time and nightto-day and day-to-night transitional periods.

The system, enclosed in a van, uses a tripled Nd:YAG laser $(355 \mathrm{~nm})$, with an average power of about $0.8 \mathrm{~W}$. 
Table 1: Position of the five COPS measurement super-sites.

\begin{tabular}{llccr}
\hline & Site & Altitude $(\mathrm{m})$ & Latitude $\left({ }^{\circ} \mathrm{N}\right)$ & Longitude $\left({ }^{\circ} \mathrm{E}\right)$ \\
\hline $\mathrm{V}$ & Meistratzheim (valley) & 150 & 48.443 & 7.545 \\
& Bishenberg (mountain) & 350 & 48.483 & 7.473 \\
$\mathrm{R}$ & Achern & 140 & 48.638 & 8.066 \\
$\mathrm{H}$ & Hornisgrinde & 1150 & 48.604 & 8.204 \\
$\mathrm{M}$ & AMF site, Heselbach & 500 & 48.545 & 8.397 \\
$\mathrm{~S}$ & Airport Deckenpfronn & 560 & 48.635 & 8.813 \\
\hline
\end{tabular}

The elastic $(355 \mathrm{~nm})$ and Raman components $(387 \mathrm{~nm}$ for molecular nitrogen and $408 \mathrm{~nm}$ for water vapour) are spectrally isolated with narrow-band $(0.4 \mathrm{~nm})$ interference filters. The transmission terms in the Raman equation are corrected with the aid of a standard atmospheric model (again midlatitude summer), while the temperature dependence of the Raman cross-section convolved with the interference filter band pass is currently neglected.

Humidity profiles are provided with a vertical resolution between $15 \mathrm{~m}$ and $300 \mathrm{~m}$. Based on an integration time of $5 \mathrm{~min}$, typical vertical range (with a random error smaller than $100 \%$ ) for night-time measurements is 6-7 km. During daytime, measurement precision is severely reduced due to the high levels of solar irradiance: the vertical range is $1-3 \mathrm{~km}$ in the day-to-night transition period and drops to a few hundred metres in the middle of the day for a temporal resolution of $10 \mathrm{~min}$ or higher. The spatial and temporal integration grids with varying resolution as a function of altitude enable the improvement of the signal-to-noise ratio, especially in upper layers where backscattered signals are usually weak. Bias in water vapour mixing ratio estimates at low signal photo-counting rates due to fluctuations in the nitrogen signal in the denominator of the ratio are corrected using the methodology presented in BOSSER et al. (2010). Finally, water vapour mixing ratio profiles are calibrated using nighttime collocated radiosondes launched at supersite $\mathrm{V}$ in the range 1-3 km (10 calibration sessions).

\subsubsection{University of Hohenheim DIAL}

The differential absorption lidar (DIAL) of the University of Hohenheim (UHOH) measures high-resolution profiles of atmospheric water vapour number density and particle backscatter ratio near $820 \mathrm{~nm}$ both during the day and at night (BEHRENDT et al., 2009, 2011b). The system consists of four novel components: A mobile laboratory mounted on a trailer, a high-power Ti:Sapphire laser transmitter (WULFMEYER and BÖSENBERG, 1996) with $\sim 4 \mathrm{~W}$ average power and a repetition rate of $250 \mathrm{~Hz}$ during COPS (WAGNER et al., 2011; WAGNER et al., 2013), a combination of a small near-field and a large far-field telescope (20 and $80 \mathrm{~cm}$ diameter primary mirrors, respectively), efficient detectors, and a high- speed data acquisition system which were developed within three interlinked projects of the German Research Foundation by UHOH, DLR Oberpfaffenhofen, Institute for Tropospheric Research Leipzig, and University of Potsdam. During COPS, the system was operated for the first time. The UHOH DIAL provides the highest resolution remote sensing data of water vapour worldwide to date see BEHRENDT et al. (2009).

DIAL is a technique which measures the water vapour number density by alternate emission of short laser pulses which are either absorbed strongly by water vapour in the atmosphere (online) or which are not absorbed (offline) and by time-resolved detection of the atmospheric backscatter signals. The UHOH DIAL employs laser radiation in the near IR between 815 and $820 \mathrm{~nm}$, a spectral region where several water vapour absorption lines are present and can be optimally selected according to the range of interest and the amount of humidity present in the atmosphere. With the water vapour absorption coefficient for the online radiation known from high-accuracy laboratory measurements, the ratio of the online and offline atmospheric backscatter profiles alone provides a profile of the water vapour number density. Consequently, no calibration of the DIAL data needs to be performed making this water-vapour active remote sensing technique very accurate.

The backscatter profiles of the DIAL are stored for each laser pulse, i.e., with $250 \mathrm{~Hz}$, and a range-resolution of $3 \mathrm{~m}$ up to $20 \mathrm{~km}$ range. Thus maximum freedom is possible in post-processing of the data. The data products of the DIAL are profiles of water vapour number density with typical resolutions of 15 to $150 \mathrm{~m}$ with a temporal resolution of 1 to $10 \mathrm{~s}$. But spatial and temporal resolution can be traded off against each other.

Based on the work of BEHRENDT et al. (2007a,b), validation efforts were carried out with the COPS water vapour lidar measurements (BHAWAR et al., 2011). It was found that the relative mean bias of the $\mathrm{UHOH}$ DIAL water vapour data (BEHRENDT et al., 2011a) to the other water vapour lidars employed during COPS is only $-1.4 \%$.

\subsubsection{GPS}

As part of the COPS instrumental set-up, the existing permanent GPS networks were enhanced with temporary 
stations to provide a $40 \mathrm{~km}$ interval GPS density. Furthermore, a denser segment of stations separated by about $10 \mathrm{~km}$ was also set up along the East-West supersites transect. GPS dual frequency data were recorded with a $30 \mathrm{~s}$ sampling interval and an elevation cut-off angle of $5^{\circ}$.

From raw GPS data, surface temperature and surface pressure, the retrievals of integrated water vapour has been extensively described in the literature since BEVIS et al. (1992) and SAASTAMOINEN (1972a,b, 1973). More details about the GPS data processing done with GAMIT software (KING and BOCK, 2009) can be found in CHAMPOLLION et al. (2009). As the processing strategy remains identical except for the Vienna Mapping Function (BOEHM and SCHUH, 2004), no emphasis is done on the GPS data processing. Typical errors in GPS integrated water vapour retrievals show a bias of $1-2 \mathrm{~kg} / \mathrm{m}^{2}$ and rms of $2 \mathrm{~kg} / \mathrm{m}^{2}$ (NIELL et al., 2001).

The LOFTTK GPS tomography software has been described with all necessary details and compared with numerical models, radiosoundings and lidar (BASTIN et al., 2005; CHAMPOLLION et al., 2009). Typical errors from the GPS tomography retrievals show a bias and a rms of about $2 \mathrm{~g} / \mathrm{kg}$ in the lower troposphere below $4 \mathrm{~km}$ and of $0.7 \mathrm{~g} / \mathrm{kg}$ in between $4-6 \mathrm{~km}$ (ChAMPOLLION et al., 2009). From raw GPS data, IWV and gradients and residuals are used to retrieve the water vapour between the ground GPS station and each GPS satellite in view every 5 minutes. A recursive least-square algorithm is used to retrieve the $4 \mathrm{D}$ field of water vapour every 15 minutes. The vertical resolution of the tomography grid is $0.5 \mathrm{~km}$ at the first level and increases up to $2 \mathrm{~km}$ at the altitude of $8 \mathrm{~km}$. The horizontal grid has been refined to match the two different resolutions of the GPS network with a resolution of $10 \mathrm{~km}$ between the supersites and of $50 \mathrm{~km}$ in the entire COPS domain. The horizontal resolution is mainly defined by separation between the nearby GPS station. The main limitation of the GPS tomography is a lack of information about the vertical distribution of water vapour from integrated ground based measurements (FLORES et al., 2000; CHAMPOLLION et al., 2005). Therefore, all radio-soundings from the COPS dataset are used during the tomography inversion without ground-based or airborne lidar data. The combination of an integrated continuous all weather system (GPS) with sparse local measurements (radio-soundings) is able to provide a realistic 4D field of water vapour at an intermediate spatial resolution.

\subsection{IASI}

The IASI instrument is a nadir-viewing Fourier transform spectrometer which records emission of the Earth atmosphere in the thermal infrared region $\left(645-2760 \mathrm{~cm}^{-1}\right)$ onboard the polar orbiting MetOp-A platform, with an apodized resolution of $0.5 \mathrm{~cm}^{-1}$. Its field of view con-
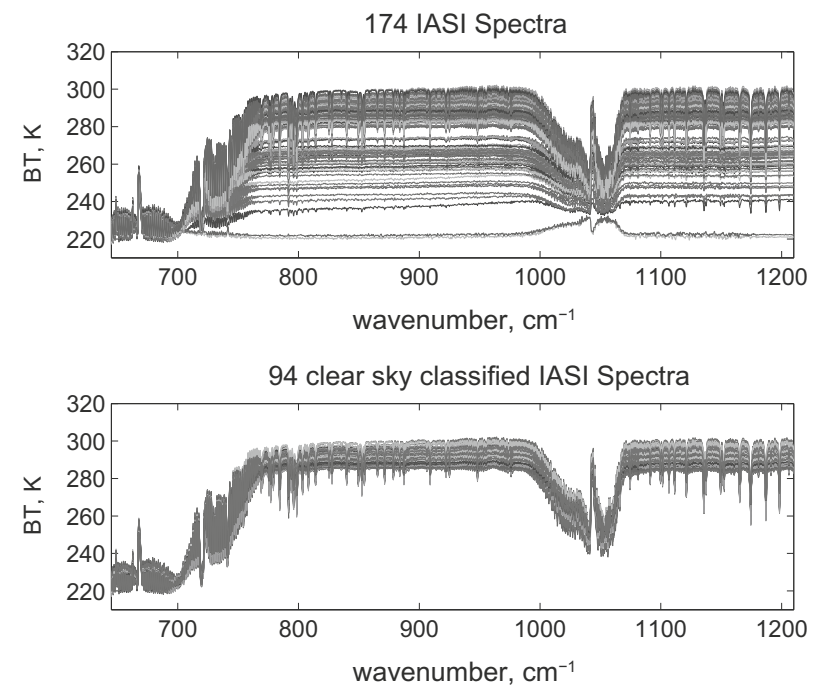

Figure 2: (upper) The whole data set of IASI spectra before cloud screening. After cloud detection only 94 out of the 174 IASI spectra were considered for the retrieval analysis (lower panel). Only the IASI band 1 is shown.

sists of a $2 \times 2$ pixel matrix with a $12 \mathrm{~km}$ pixel footprint on the ground at nadir. A swath across the track of $2200 \mathrm{~km}$ ensures a global coverage of twice per day (HILTON et al., 2012). The IASI specifications, which are detailed in HiLTON et al. (2012), allow the retrieval of temperature and tropospheric water vapour profiles with an accuracy of $1 \mathrm{~K}$ and $15-20 \%$ respectively (HILTON et al., 2012) and a vertical resolution of 1 and $2 \mathrm{~km}$. The satellite ground track is at about 09:30 local time in the morning and 21:30 in the evening.

The set of IASI observations we have considered for the present analysis consists of 174 IASI spectra, which have been acquired over the period June-August 2007 and are shown in Fig. 2. These spectra were passed through the IASI stand alone scene analysis (SERIO et al., 2000; MASIELLO et al., 2002a, 2003, 2004; GRIECO et al., 2007) for cloud screening. In the end, only 94 out of the original 174 spectra were considered for the retrieval of surface and atmospheric parameters. Of these 94 spectra, eventually 71 converged according to quality checks embedded within the retrieval schemes. These 71 spectra and related products formed the basis of the present inter-comparison.

In passing, we note that within the set of 174 original IASI observations, we were able to detect a series of IASI inverted spectra (see Fig. 3), in which the strong $\mathrm{CO}_{2}$ absorption near $14 \mu \mathrm{m}$ and ozone absorption at $9.6 \mu \mathrm{m}$ are seen in emission relative to cold cloud tops in the $8-12 \mu \mathrm{m}$ spectral range in atmospheric window channels. These inverted spectra occurred on the night of 23 July 2007 and show evidence that an overshooting convection was acting at that time. Overshooting convection happens when the cloud top reaches the level of the tropopause, an event which can yield extremely heavy rain 


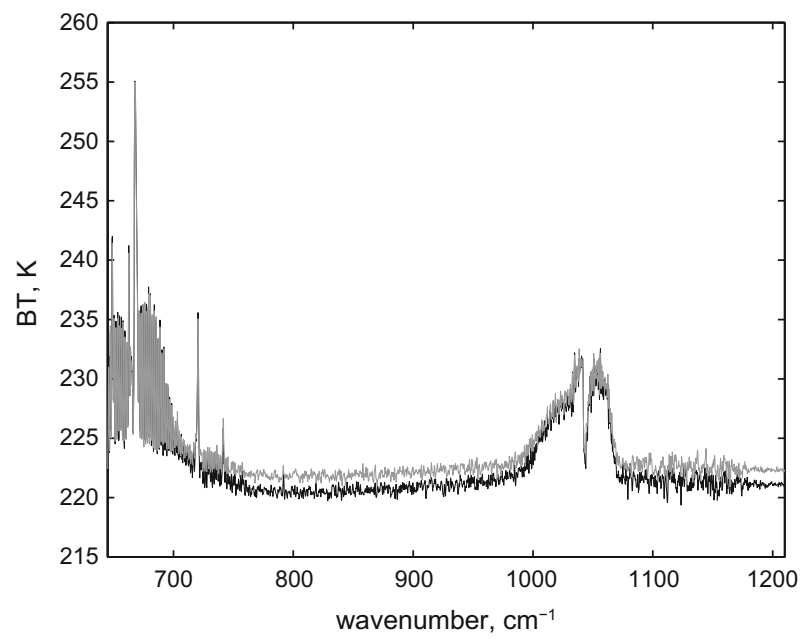

Figure 3: A couple of IASI spectra showing the occurrence of overshooting convection during the night of 23 July 2007. Only the IASI band 1 is shown.

and is normally found in the tropical region. Fig. 3 shows that overshooting convection can also occur at mid-latitudes and IASI is capable of detecting these extreme meteorological events.

\subsubsection{IASI-L1C water vapour profile retrievals at LATMOS}

For the purpose of this study, water vapour profiles are retrieved from the L1C IASI apodized radiance spectra using the Atmosphit software developed at Université Libre de Bruxelles, Belgium (BARRET et al., 2005a,b; COHEUR et al., 2005) based on a line-by-line radiative transfer calculation and the application of the Optimal Estimation Method (RoDGERS, 2000). The theoretical elements underlying such a method are similar to HERBIN et al. (2009) and LACOUR et al. (2012).

The $\mathrm{H}_{2}{ }^{16} \mathrm{O}$ profiles are retrieved on 10 discrete vertical layers, extending from the ground up to $20 \mathrm{~km}$ in $2 \mathrm{~km}$ intervals (e.g., 0-2, 2-4, ..., 18-20 km). In the spectral range used, the surface temperature, and the tropospheric columns of $\mathrm{HDO}, \mathrm{H}_{2}{ }^{17} \mathrm{O}, \mathrm{H}_{2}{ }^{18} \mathrm{O}, \mathrm{CO}_{2}, \mathrm{CH}_{4}$, $\mathrm{HNO}_{3}, \mathrm{~N}_{2} \mathrm{O}$, are adjusted simultaneously. However, the effect of these parameters on the water vapour retrieval is very weak as shown in Fig. 4. The temperature profiles and surface emissivity are treated as non-retrieved parameters. The a priori values and variabilities of all parameters are detailed hereafter.

For this study, we constructed the background vector and covariance matrix in the following way. To begin with, the a priori vector has been derived from the absolute humidity profiles, $\phi$ in the ERA (ECMWF Re-Analysis)-Interim data (see Fig. 1 for the size of the domain over which the a priori vector was computed). The humidity profiles were converted into water mass mixing ratios using Tetens's formula (TETENS, 1930) to determine the water equilibrium vapour pressure $p_{\text {sat }}^{\mathrm{H}_{2} \mathrm{O}}$ (in $\mathrm{hPa}$ )
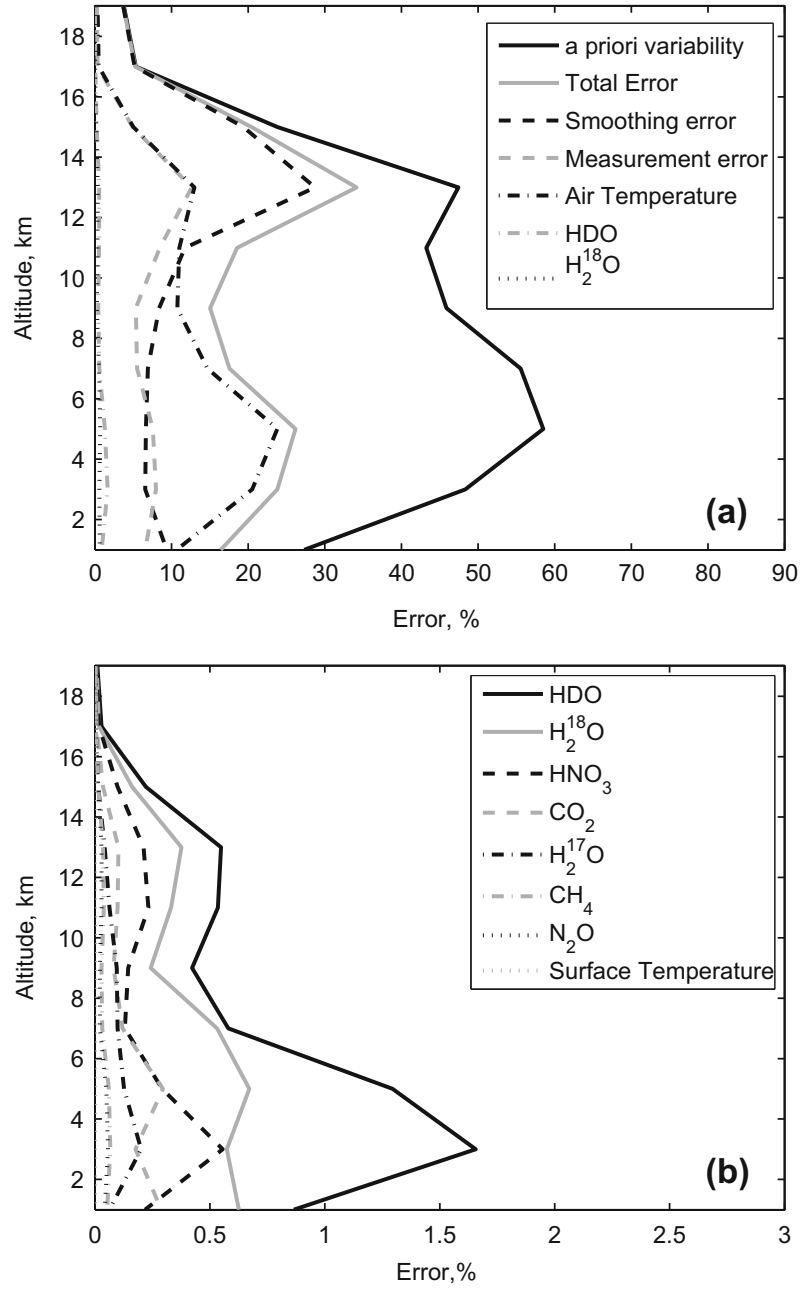

Figure 4: (a) Mean error profiles over the 71 retrieved spectra and (b) replotted over the range $0-3 \%$ to show the error profiles of the interfering gases.

$$
p_{\text {sat }}^{H_{2} \mathrm{O}}(T)=611 \exp \left[7.5 \log (10) \frac{T-273.15}{T-35.85}\right] .
$$

where $T$ is the temperature (in $\mathrm{K}$ ). From the water equilibrium vapour pressure, we can determine the water vapour mass mixing ratios, using

$$
q=\frac{\left(\gamma \phi p_{s a t}^{H_{2} O}(T)\right)}{\left(P-\phi p_{s a t}^{H_{2} O}(T)(1-\gamma)\right)}
$$

and

$$
M M R=\frac{q}{(1-q)} .
$$

where $q$ is the specific humidity and $\gamma=R_{\text {spec }}^{d r y} / R_{\text {spec }}^{H_{2} O}$ is the ratio of the dry air specific constant over the water vapour specific constant.

The a priori state vector, $x_{a}$ and its corresponding variance-covariance matrix, $C_{a}$ were built using ERAinterim mixing ratio profiles on a $1 \mathrm{~km}$ grid going from 0 to $20 \mathrm{~km}$. This data covers a three year period 
(2004-2006), focused on the three months of summer (June to August) on a spatial range of $46.5-51^{\circ} \mathrm{N}$; $3-12^{\circ} \mathrm{E}$ (Fig. 1) on a $0.75^{\circ} \times 0.75^{\circ}$ grid. The reduced a priori variance-covariance matrix, $S_{a}$ is

$$
S_{a}=\operatorname{diag}\left(\frac{1}{x_{a}}\right) C_{a} \operatorname{diag}\left(\frac{1}{x_{a}}\right)
$$

This method ensures the possibility of starting the retrievals with good a priori knowledge of the concentrations of water vapour without being too much of a constraint (see Fig. 5). Other a priori vectors as well as other covariance matrices have been tested, but showed no significant impact on the retrievals. This can be explained by the fact that the smoothing error is of the same order of magnitude as the measurement error in the lower atmospheric layers.

As far as the forward model is concerned, spectroscopic parameters derived from the HITRAN 2008 database (ROTHMAN et al., 2009) were used to perform this study. The selected spectral window is 1186.95 to $1406.40 \mathrm{~cm}^{-1}$ with a gap between 1300.75 and $1307.25 \mathrm{~cm}^{-1}$, thus removing the contribution of the methane $\mathrm{Q}$ branch in the $v_{4}$ band. This range is optimized for water vapour retrieval and unlike the method used in HERBIN et al. (2009), we did not take into account the shortwave spectral window above $2500 \mathrm{~cm}^{-1}$ as we were not interested in proper retrievals of HDO. Moreover, tests conducted in this study using this window showed no significant effect on the results for $\mathrm{H}_{2}{ }^{16} \mathrm{O}$.

For the IASI measurement error covariance matrix, we use a diagonal matrix whose elements are set equal to $2 \times 10^{-6} \mathrm{~W} /\left(\mathrm{cm}^{2} \mathrm{sr} \mathrm{m}^{-1}\right)$, which is the typical IASI radiometric noise for the spectral range used in the analysis.

As far as values and settings regarding model parameters, land surface temperatures were derived from the MODIS Terra data on a daily basis. Emissivities were also derived from MODIS Terra on a monthly basis. They were calculated following equation (12) proposed by WANG et al. (2005).

Temperature profiles came from the DIFA retrieval (see Section 2.2.2). IASI DIFA profiles were compared to those retrieved from GPS tomography, and appeared to show rather small overall differences. They also helped in minimising the air temperature bias associated with LATMOS profiles a posteriori with respect to the GPS tomography temperature profiles. They were treated as equivalent to level 2 IASI temperature profiles, assuming an uncorrelated uncertainty of $1 \mathrm{~K}$ for each retrieved layer. For the other model parameters, we used climatology and the uncertainty associated is that specified in HERBIN et al. (2009).

Following RODGERS (2000), who expands the retrieval error in its components (smoothing error, model parameter error and retrieval noise), Fig. 5 shows the contribution to the retrieval (total) error from the various
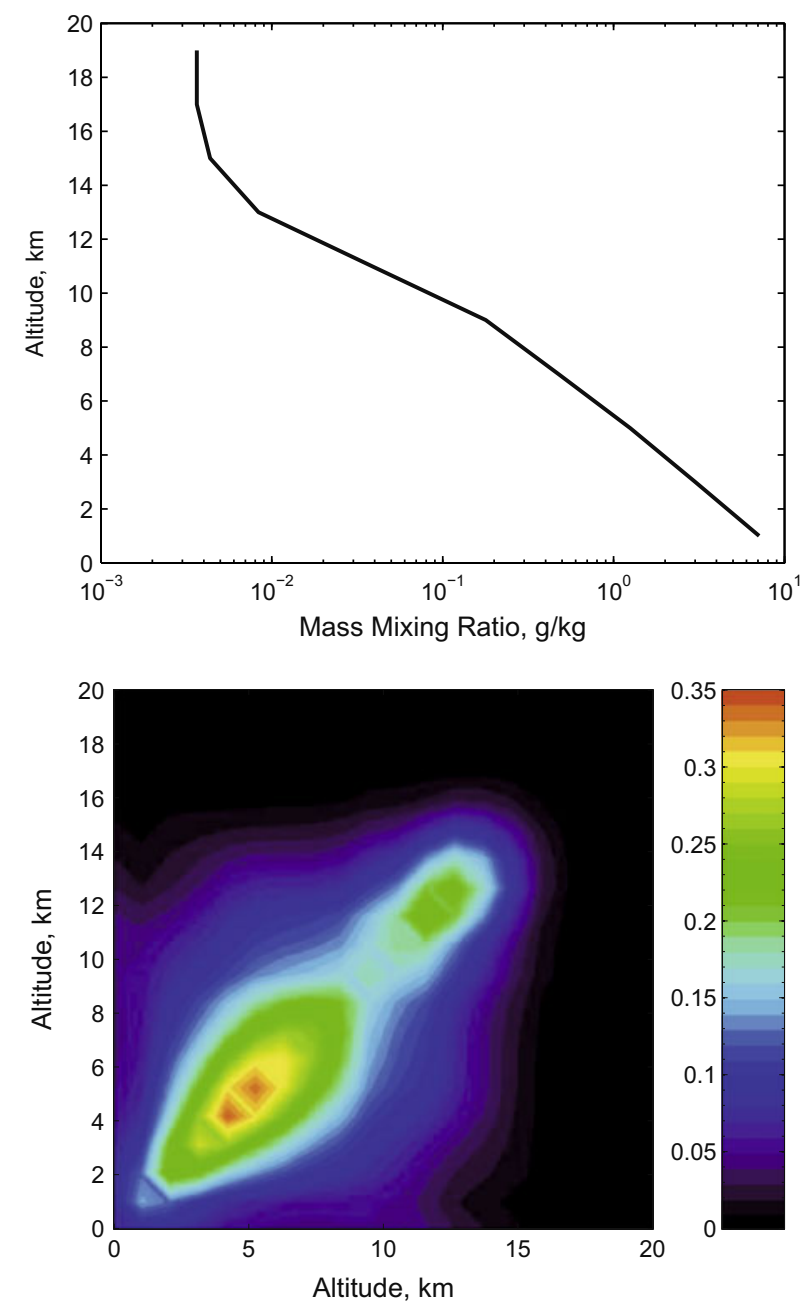

Figure 5: Altitude plotted as a function of a priori water vapour mass mixing ratio profile on a logarithmic scale (upper panel) and its associated reduced water vapour covariance matrix (Sa) projection (bottom panel).

sources of noise. The error analysis has been averaged over the 71 retrieved water vapour profiles. The first thing to be pointed out is that the interfering species (model parameters) have a minor impact on the retrieval error for the water vapour profile, which is in agreement with the previous work of HERBIN et al. (2009). It can also be seen that the total error is slightly larger than what has been shown in HERBIN et al. (2009) with a value close to $20 \%$ below $12 \mathrm{~km}$. This is mainly due to the difficulty in performing a meaningful retrieval near the surface over complex terrain like the one present in the COPS area. The largest errors are observed in the $1-7 \mathrm{~km}$ and the $11-15 \mathrm{~km}$ layers where the main contributions are due to errors in air temperature (mainly in the $1-5 \mathrm{~km}$ layer) and smoothing (mainly in the $11-15 \mathrm{~km}$ layer, see Fig. 6). The contribution of the smoothing error is depicted in Fig. 6 which shows the lack of resolution above $11 \mathrm{~km}$. Fig. 6 also shows that the states retrieved in the altitude range $1-11 \mathrm{~km}$ are a good description of the real state at that altitude range. 


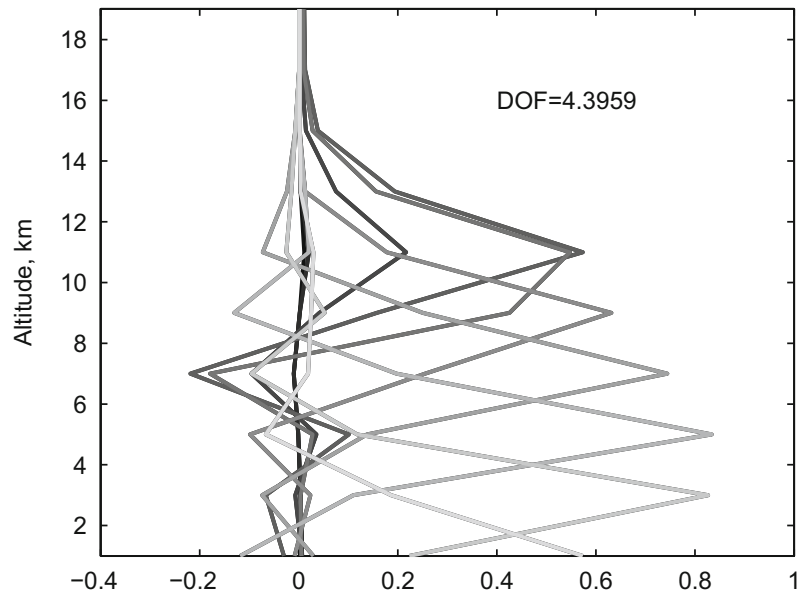

Figure 6: Rows of the mean averaging kernel matrix calculated over the 71 IASI retrievals at LATMOS.

\subsubsection{IASI-L1C water vapour profile retrievals at DIFA}

The retrieval products for this experiment are obtained with the DIFA $\varphi$-IASI package (GRIECO et al., 2007; MASIELLO et al., 2009; MASIELlO and SERIO, 2013) which is intended to generate IASI synthetic spectra and for the inversion of the following geophysical parameters: surface temperature and emissivity, temperature and water vapour profiles, low vertical resolution profiles of ozone, carbon monoxide, methane, and nitrous oxide.

This package is intended to provide a kit of models to address research issues on inversion methodology (including Tikhonov and/or Rodgers regularization, Levenberg-Marquardt least-square minimization) and radiative transfer (including generation of analytical derivative matrices, impact of new spectroscopy).

The package has been the subject of various scientific papers and, in addition, it has been extensively validated using aircraft and satellite high spectral resolution infrared observations recorded with Fourier transform spectrometers (GRIECO et al., 2007; TAYLOR et al., 2008).

It consists of a stand-alone cloud detection scheme (MASIELLO et al., 2002b), a forward model, $\sigma$-IASI (AMATO et al., 2002) and an inverse model, $\delta$-IASI (CARISSIMO et al., 2005).

The forward model, which we call $\sigma$-IASI, consists of a monochromatic radiative transfer model which has been designed for the fast computation of spectral radiance and its derivatives (Jacobian) with respect to a given set of geophysical parameters. It computes monochromatic radiances from look-up-tables of monochromatic layer optical depth generated by the line-by-line radiative transfer model LBLRTM (CLOUGH et al., 2005). The atmospheric layering embedded in $\sigma$-IASI consists of 60 pressure layers extending from 1050 to $0.005 \mathrm{hPa}$. In the middle-to-lower troposhere, the layering enables us to perform forward/inverse calculations on a mesh with a grid step better than $1 \mathrm{~km}$.
The inverse module, which we call $\delta$-IASI, implements a non-linear inversion procedure, needs to be properly initialized as there may be multiple solutions due to the ill-posed nature of the retrieval problem. For the present study, the initialization is provided by the Empirical Orthogonal Function (EOF) statistical retrieval approach described in GRIECO et al. (2005); SERIO et al. (2009).

The basic implementation of the inverse scheme follows Rodgers's statistical regularization method (RODGERS, 1976). However, an additional regularization parameter (CARISSIMO et al., 2005; MASIELLO and SERIO, 2013) is introduced in the inverse scheme, which improves the retrieval accuracy and constrains the step size of Newton updates in such a way as to iterate towards the likely region of the inverse solution (GRIECO et al., 2007; CARISSIMO et al., 2005; MASIELLO and SERIO, 2013). For the background vector, we use the EOF retrieval for the surface temperature and temperature profile, whereas the time-space colocated ECMWF analysis is used for water vapour and ozone. The covariance matrix is the forecast error obtained from the EOF regressions scheme. The EOF regression scheme is tuned with the Chevallier ECMWF data set (CHEVALLIER, 2001). We do not use the ECMWF analysis error because this provides too tight of a constraint. Also, as said, our scheme uses an additional regularization parameter that tries to balance the covariance matrix on the basis of the given observations (CARISSIMO et al., 2005). For the purpose of developing a suitable background for emissivity, we use the University of Wisconsin (UW) Baseline Fit (BF) Emissivity database (UW/BFEMIS database, e.g. http://cimss.ssec.wisc.edu/iremis/ (SEEMANN et al., 2008; MASIELlO and SERIO, 2013).

For the present study, the retrieved state vector includes: surface temperature and emissivity, temperature, water vapour and ozone profiles. The columnar amount of water vapour or equivalently the precipitable water, $p w$ is directly obtained through integration over the estimated water vapour mixing ratio, $\hat{q}(p)$, according to

$$
p w=\frac{1}{g} \int_{o}^{p_{o}} \hat{q}(p) \mathrm{d} p .
$$

where $p_{o}$ is the pressure at the ground level, $\hat{q}(p)$ is the water vapour mixing ratio profile $(\mathrm{kg} / \mathrm{kg}), g=9.81 \mathrm{~m}$ $\mathrm{s}^{-2}$ is the acceleration of gravity at sea level. Using International System units, the above integral is in $\mathrm{kg} \mathrm{m}^{-2}$. Since, the water vapour profile is obtained at $N=60$ atmospheric layers, we have

$$
p w=\frac{1}{g} \sum_{i=1}^{N} \hat{q}(i) \Delta p(i)
$$

with precision, $\sigma_{p w}^{2}$ given by

$$
\sigma_{p w}^{2}=\frac{1}{g^{2}} \sum_{i=1}^{N} \sum_{j=1}^{N} S(i, j) \Delta p(i) \Delta p(j) .
$$


where $S(i, j), i, j=1, \ldots, N$ are the elements of the water vapour a-posteriori covariance matrix. The precision can depend on the given retrieval. However, normally it is less than $1.0 \mathrm{~kg} \mathrm{~m}^{-2}$.

For the present study, the following spectral ranges have been considered for the inversion of IASI data: 645 to $1250 \mathrm{~cm}^{-1} ; 1450$ to $2260 \mathrm{~cm}^{-1}$. At the IASI sampling rate of $0.25 \mathrm{~cm}^{-1}$, this corresponds to a number of 5668 IASI spectral radiances. The observational covariance matrix is assumed diagonal. The diagonal is the wave-number dependent IASI radiometric noise. Further details about spectral ranges, the observational covariance matrix, background vector and covariance and the expected retrieval performance can be found (GRIECO et al., 2007; MASIELLO et al., 2009, 2012; MASIELlO and SERIO, 2013), to which the interested reader is referred.

For the benefit of the reader, we note that the mean observed error in the lower troposphere $(0-6 \mathrm{~km})$ is $0.6 \mathrm{~g} / \mathrm{kg}(11 \%)$ with values ranging from $0.08 \mathrm{~g} / \mathrm{kg}$ to $0.84 \mathrm{~g} / \mathrm{kg}$, with a relative error ranging from 8 to $16 \%$. Above $6 \mathrm{~km}$, observed errors are between $0.002 \mathrm{~g} / \mathrm{kg}$ and $0.05 \mathrm{~g} / \mathrm{kg}$, with relative differences increasing with altitude from $11 \%$ to $70 \%$ for the higher layer $(0.05 \mathrm{hPa})$, and a mean value of $0.01 \mathrm{~g} / \mathrm{kg}(40 \%)$.

As far as the vertical spatial resolution capabilities and properties of $\delta$-IASI are concerned, they have been assessed in GRIECO et al. (2007) in terms of degrees of freedom and averaging kernels. For water vapour, based on our typical background covariance matrix, we have 8-9 degrees of freedom for temperature, 7-8 for water vapour and 2-3 for ozone. Furthermore, in the first $3 \mathrm{~km}$ altitude range of the atmosphere, the spatial vertical resolution for water vapour is between $0.5-1 \mathrm{~km}$. However, we have to caution that degrees of freedom and averaging kernels depend on the given background covariance matrix and cannot be assumed as a universal measure of the IASI capability for resolving spatial vertical structures of water vapour. It has been shown (GRIECO et al., 2007) that degrees of freedom characterizes the retrieval system and not the IASI capability to resolve vertical spatial structures. Nevertheless, degrees of freedom and averaging kernels tend to be associated as a universal measure of the performance of a given instrument (such as IASI) rather than the given retrieval method. For cases where an important atmospheric feature is unresolved, it is generally the fault of the retrieval methodology rather than the instrument itself (GRIECO et al., 2010).

\section{Water vapour comparisons}

The comparisons between the different techniques are divided to two parts. The first part is dedicated to an assessment of the quality of the total columnar amount of water vapour by a comparison between the two IASI retrieval techniques (LATMOS and DIFA) presented in the previous section. These two methods are then compared to the GPS columnar amounts as measured during the COPS campaign.

The second part is dedicated to the comparison of the vertical water vapour profiles. As for the total columns, the comparison is done between the two IASI-based retrieval techniques, as well as with the GPS tomography measurements and the BASIL Raman lidar profiles. In addition, radiosoundings, DIAL and Rameau lidar comparisons are shown when data are available.

Comparisons are done using 71 IASI L1C spectra that were selected close to the COPS GPS stations (less than $6 \mathrm{~km}$ ) in order to have the most accurate spatial colocation (see Fig. 1).

\subsection{Total column comparisons}

For what concerns the inner comparison between the two IASI retrieval techniques, the column integrated water vapour values are determined from the spectra using different spectral regions for the two methods as described in the previous section.

The comparison (Fig. 7a) shows a small positive bias (LATMOS column integrated values larger than DIFA's), but a very good overall agreement with a correlation coefficient of about 0.85 and a root mean square difference (RMSD, $2.56 \mathrm{~kg} / \mathrm{m}^{2}$ ) larger than the mean errors associated with the two retrieval techniques $(2.30 \mathrm{~kg} /$ $\mathrm{m}^{2}$ and less than $1 \mathrm{~kg} / \mathrm{m}^{2}$ for LATMOS and DIFA retrieval, respectively). More details are in Tables 2 and 3.

The comparisons between the GPS column integrated water vapour measurements and LATMOS and DIFA retrievals are illustrated in Fig. 7b and Fig. 7c, respectively. A positive bias is observed (IASI retrievals larger than GPS) for the two techniques $\left(3.05 \mathrm{~kg} / \mathrm{m}^{2}\right.$ or $15 \%$ in the case of LATMOS, $0.33 \mathrm{~kg} / \mathrm{m}^{2}$ or $2 \%$ in the case of DIFA), with a higher correlation coefficient $(\sim 0.92)$, which reveals an overall good agreement between the IASI retrieval methods and the GPS measurements.

The results obtained with two different and independent retrieval techniques show a good consistency which is strengthened by the comparison with the GPS measurements, even though in both cases a small positive difference with GPS observations is observed.

\subsection{Profile comparisons}

The second part of the comparison effort is mostly devoted to the capability of the two IASI retrieval methodologies to resolve double-layer water vapour structures in the lower troposphere.

All comparisons are expressed in terms of water vapour mixing ratio $(\mathrm{g} / \mathrm{kg})$. As for the column integrated contents, we also show a comparison between the IASI retrievals at LATMOS and DIFA. Comparisons with the COPS data involve different measurement 

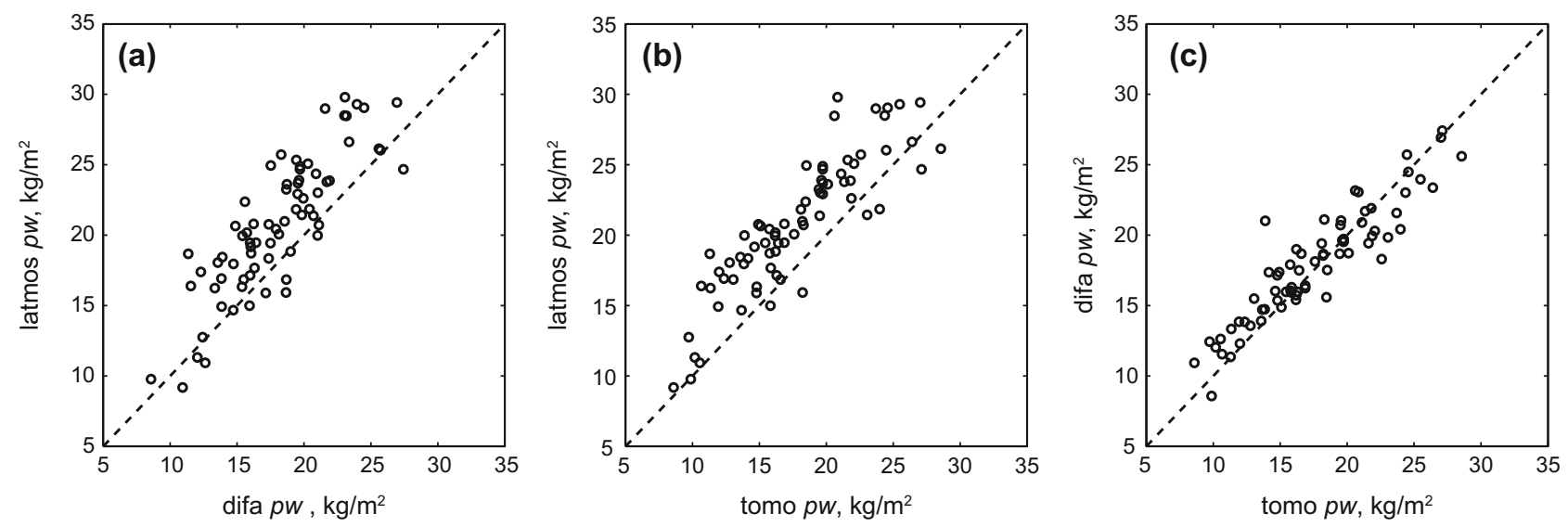

Figure 7: Comparisons in terms of column integrated water vapour or equivalently Precipitable Water (pw): (a), DIFA vs. LATMOS IASI retrievals; (b) LATMOS IASI retrievals vs. GPS; c) DIFA IASI retrievals vs. GPS.

Table 2: Mean and standard deviation for the water vapour columnar amount seen by the tomography (second column), $\delta$-IASI (third column) and latmos (fourth column). Mean and standard deviation of the columnar amounts have been calculated over the subset of 71 IASI spectra for which both the retrieval methodologies converged. The last row shows the results for the whole troposphere.

\begin{tabular}{cccc}
\hline Altitude $(\mathrm{km})$ & Tomo $\left(\mathrm{kg} / \mathrm{m}^{2}\right)$ & difa $\left(\mathrm{kg} / \mathrm{m}^{2}\right)$ & latmos $\left(\mathrm{kg} / \mathrm{m}^{2}\right)$ \\
\hline $0-2$ & $9.1 \pm 2.3$ & $9.7 \pm 2.4$ & $8.8 \pm 2.0$ \\
$2-4$ & $5.8 \pm 2.2$ & $5.2 \pm 2.4$ & $7.8 \pm 2.2$ \\
$4-6$ & $1.9 \pm 0.9$ & $2.2 \pm 0.9$ & $3.0 \pm 1.0$ \\
$6-8$ & $0.7 \pm 0.3$ & $0.7 \pm 0.3$ & $0.9 \pm 0.4$ \\
$8-10$ & $0.20 \pm 0.08$ & $0.2 \pm 0.1$ & $0.3 \pm 0.1$ \\
$10-12$ & $0.11 \pm 0.06$ & $0.05 \pm 0.02$ & $0.06 \pm 0.02$ \\
\hline $0-12$ & $17.7 \pm 4.7$ & $18.0 \pm 4.00$ & $20.8 \pm 4.8$ \\
\hline
\end{tabular}

Table 3: This table shows correlation coefficients $(r)$, mean differences $(m d)$ and root mean squared differences $(r m s d)$ among the columnar amount of water vapour coming from the two IASI retrievals and the GPS tomography. The last row shows the results for the whole troposphere.

\begin{tabular}{|c|c|c|c|c|c|c|c|c|c|}
\hline \multirow[b]{2}{*}{ Altitude (km) } & \multicolumn{3}{|c|}{ difa-latmos } & \multicolumn{3}{|c|}{ difa - Tomo } & \multicolumn{3}{|c|}{ latmos-Tomo } \\
\hline & \multicolumn{3}{|c|}{$\left(\mathrm{kg} / \mathrm{m}^{2}\right)$} & $r$ & $m d$ & rmsd & $r$ & $m d$ & rmsd \\
\hline $0-2$ & 0.81 & 0.97 & 1.40 & 0.90 & 0.67 & 1.03 & 0.82 & -0.30 & 1.33 \\
\hline $2-4$ & 0.64 & -2.59 & 1.94 & 0.78 & -0.62 & 1.52 & 0.87 & 1.97 & 1.11 \\
\hline $4-6$ & 0.70 & -0.78 & 0.79 & 0.48 & 0.29 & 0.88 & 0.68 & 1.06 & 0.81 \\
\hline $6-8$ & 0.87 & -0.26 & 0.18 & 0.39 & 0.03 & 0.31 & 0.44 & 0.29 & 0.33 \\
\hline $8-10$ & 0.90 & -0.06 & 0.05 & 0.26 & 0.02 & 0.10 & 0.32 & 0.08 & 0.12 \\
\hline $10-12$ & 0.83 & -0.01 & 0.01 & 0.19 & -0.06 & 0.06 & 0.30 & -0.05 & 0.06 \\
\hline $0-12$ & 0.85 & -2.72 & 2.56 & 0.92 & 0.33 & 1.87 & 0.88 & 3.05 & 2.36 \\
\hline
\end{tabular}

techniques: specifically, radiosoundings and several remote sensing devices (BASIL Raman lidar, $\mathrm{UHOH}$ DIAL, Rameau lidar and GPS tomography). It should be pointed out that data from the UHOH DIAL, BASIL and the Rameau lidar data were integrated over ten minutes in order to reduce signal fluctuations and sampling errors for the comparisons. It is to be also pointed out that DIAL systems measure water vapour number density profiles, while Raman lidars measure water vapour mixing ratio. Water vapour mixing ratio profiles for the DIAL were calculated from the measured number density profiles using the conversion formula described by equation (1) in the previous work of BHAWAR et al. (2011).

Because the various methods and techniques have quite different vertical spatial resolution, we have also projected the diverse profiles in the retrieval space of the LATMOS method, which is that with lower vertical spatial resolution (at best $2 \mathrm{~m}$ in the altitude range 

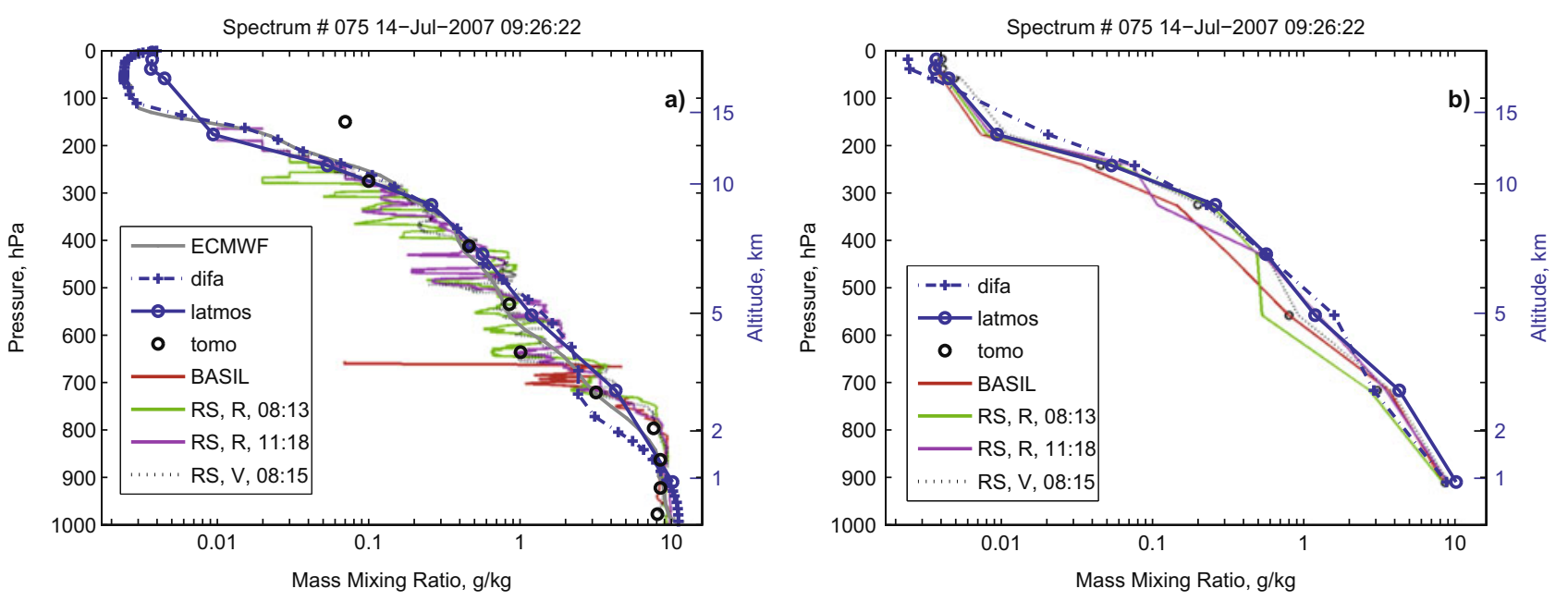

Figure 8: IASI L1C-retrieved water vapour profiles comparison. (a) original profiles. (b) smoothed profiles. Location : $48.66^{\circ} \mathrm{N} ; 7^{\circ} 94^{\circ} \mathrm{E}$ at 09:26:22 UTC. The R-site and V-site are approximatively $9 \mathrm{~km}$ and $38 \mathrm{~km}$ far from the center of the IASI footprint. The radiosondes from the R-site were launched at 08:13 (Green line) and 11:18 (Magenta line) while the radiosonde from the V-Site was launched at 08:15 (black dotted line). In panel a), the co-located ECMWF analysis profile is shown in grey.

$0-20 \mathrm{~km})$. This is done by degrading the higher resolution profiles by means of the smoothing function described by CONNOR et al. (1994) according to the following equation:

$$
x_{S}=x_{a}+A\left(x_{h}-x_{a}\right),
$$

where $x_{h}$ is the higher resolution profile, $A$ is the LATMOS averaging kernels matrix (see references (RODGERS, 2000; HERBIN et al., 2009) $x_{a}$ is the a priori and $x_{s}$ is the resulting smoothed profile, respectively.

Before smoothing is done, profiles with missing values below $20 \mathrm{~km}$ are completed using a climatology profile calculated from the ERA Interim humidity profiles over the COPS region and time of operation, using the same methodology as described in the a priori building paragraph in section 2.2.1.

An example of retrieved profiles compared to COPS measurements is shown in Fig. 8. This profile shows a simple single layer structure in the lower troposphere and all methods are capable of capturing this simple feature. The overall consistency is good also considering the imperfect co-location among COPS measurements and IASI observations.

Much more interesting is the comparison provided in Fig. 9, which shows two water vapour profile exhibiting a two-layer structure in the lower troposphere. For the case of the spectrum 92 recorded on 25 July 2007 at 20:24:36 UTC, we have a very large dry layer about $5 \mathrm{~km}$ in width. It is seen that DIFA retrieval easily detects this large dry structure. LATMOS is a bit more smoothed, which is easily explained because of the 2-km vertical grid mesh used by this method. Also, the smooth LATMOS representation in the same figure shows that DIFA detects very nicely the dry layer.
The second profile in Fig. 9 (corresponding to the date 31 July 2007, 20:00:34 UTC) is even more interesting, because the dry layer has now a width of less than $2 \mathrm{~km}$, which is below the detecting capability of LATMOS. And in fact, this last scheme is not capable of revealing the double-layer structure. Conversely, DIFA is quite able to pick up the correct position of the dry layer. Given the approximate colocation, this is again a very good result. We think that this capability has not only to do with the finer vertical grid mesh of DIFA compared with LATMOS also reflects the fact the DIFA uses ECMWF analysis as the background vector for water vapour.

A comparison in terms of mean and standard deviation of the difference among the diverse schemes is here limited to LATMOS, tomography and DIFA, which are perfectly co-located with the IASI observations. A comparison is made by using the LATMOS vertical grid mesh as reference (this is made of layers with a constant width of $2 \mathrm{~km}$ ). For the first $12 \mathrm{~km}$ altitude, the layerintegrated water amount is shown in Tables 2 and 3. For the benefit of the reader, the same data points are graphically represented in the Fig. 10.

The first interesting feature we can see from this figure is the fact that the most biased layer from the groundlevel, is the second one, e.g. layer 2-4 km. From Fig. 9, this is the altitude range where the dry layer tended to develop the double-layer structure. It is also quite interesting to note that while the mean difference between GPS tomography (TOMO) and DIFA is limited to $0.4 \mathrm{~mm}$, the TOMO-LATMOS and DIFA-LATMOS differences can reach values as high as $2 \mathrm{~mm}$. A second interesting feature is that the standard deviation begins to be of the same order of the mean values as the altitude increases. This is also confirmed by the data shown in 

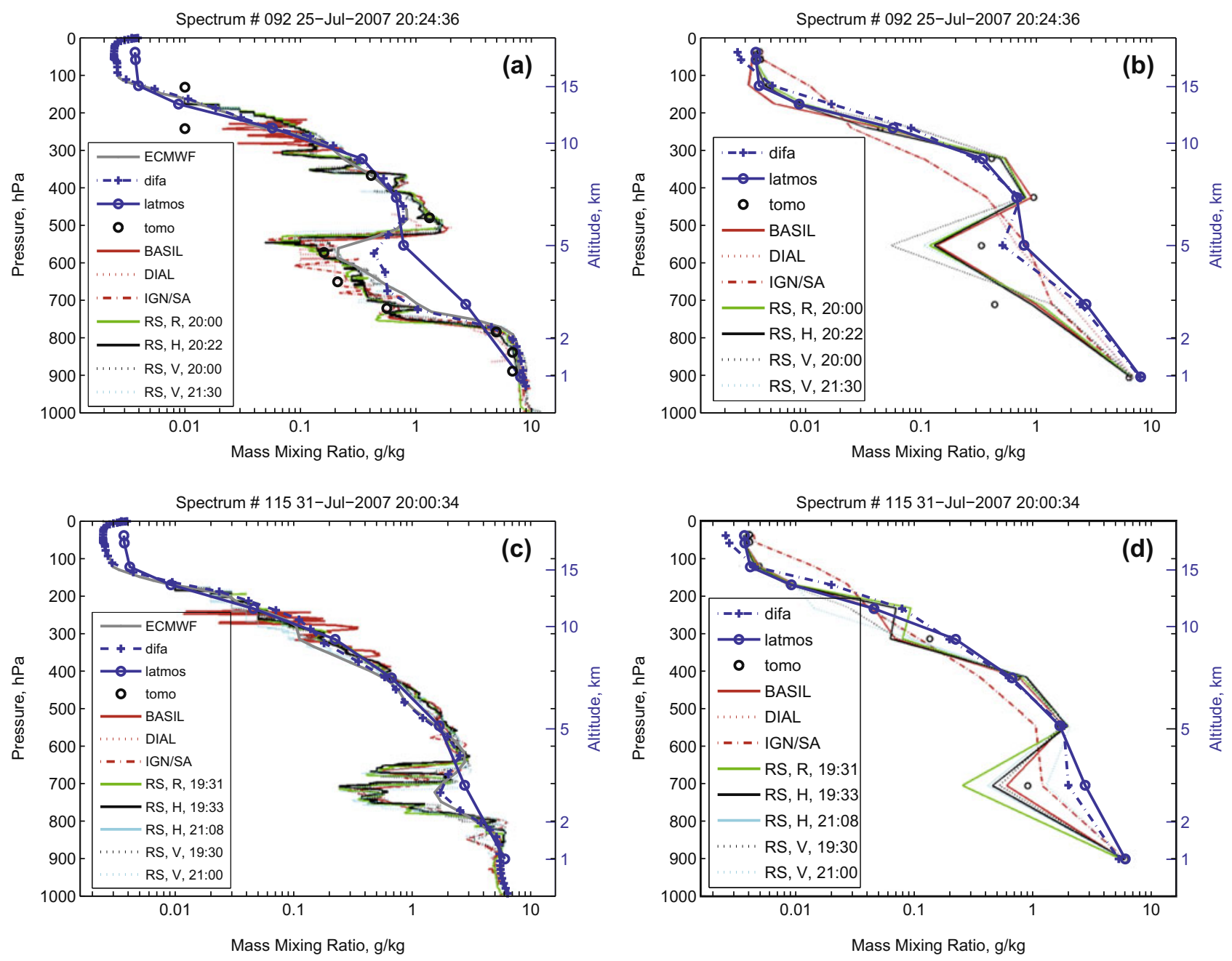

Figure 9: IASI L1C-retrieved water vapour profiles comparison. Left panels (a and c) are the original profiles, while the right (b and d) panels are the smoothed profiles. Locations (from top to bottom) : $47.99^{\circ} \mathrm{N} ; 8.44^{\circ} \mathrm{E}, 47.84^{\circ} \mathrm{N} ; 7.42^{\circ} \mathrm{E}$. The spectrum in the upper panel was recorded on the $24^{\text {th }}$ of July 2007 at 20:24:36 UTC. In this case the R-site, H-site and V-sites are approximatively $76 \mathrm{~km}, 69 \mathrm{~km}$ and $83 \mathrm{~km}$ from the center of IASI footprint, respectively. The radiosondes were launched at 20:00 (Green line) from the R-site, at 20:22 (black solid line) from the H-Site, at 20:00 (black dotted line) and 21:30 (cyan dotted line) from the V-Site. The spectrum in the lower panel was recorded on the $31^{\text {th }}$ of July 2007 at at 20:00:34 UTC. In this case, the R-site, H-site and V-sites are approximatively $101 \mathrm{~km}, 103 \mathrm{~km}$ and $68 \mathrm{~km}$ far from the center of IASI footprint. The radiosondes were launched at 19:31 (Green line) from the R-site, at 19:33 (black solid line) and 21:08 (cyan solid line) from the H-Site, at 19:30 (black dotted line) and 20:00 (cyan dotted line) from the V-Site. In the panels a) and c), co-located ECMWF analysis profiles are shown in grey.

Table 3, which shows the correlation coefficients layerby-layer between TOMO-DIFA, DIFA-LATMOS and TOMO-LATMOS.

This analysis parallels that shown in SCHNEIDER and HASE (2011), although we use GPS-tomography instead of radiosonde observations and our target area consists of a complex surface, instead of a smooth sea surface. What we see from Table 3 is that the water vapour TOMO tends to be uncorrelated with IASI products above $8 \mathrm{~km}$ altitude. This is quite close to the tropopause height, where IASI is expected to have a poor sensitivity. In general, LATMOS and DIFA are well correlated, which is a good internal consistency check because both algorithms use the same observations.

\section{Conclusions}

We have performed a comparison study of IASI products to COPS campaign measurements, taken with different technology and methods.

IASI products were derived with two different algorithms, the first one (LATMOS) specialized for water vapour and the second one (DIFA) for the simultaneous retrieval of surface and atmospheric parameters. While LATMOS uses a coarse vertical grid in the lower troposphere (2 km width layers), DIFA is based on an atmospheric layering better than $1 \mathrm{~km}$ in the middle-tolower troposphere. The two also rely on a very different background vector and covariance. LATMOS uses 


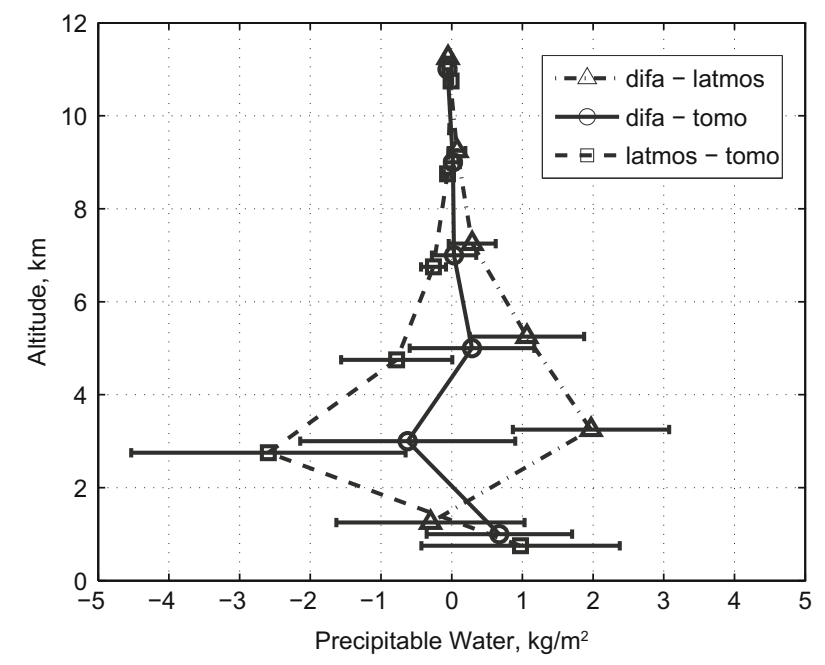

Figure 10: Mean and root mean square differences between difa, latmos and gps retrievals.

climatology, DIFA (for water vapour) relies on the timespace colocated ECMWF analysis.

The comparison with water vapour profiles derived from vertical spatial resolution techniques and methods has allowed us to get a better insight into the capability of IASI of resolving two-layer structures in the lower troposphere. Mostly depending on the background, we have once more shown that infrared observations of high spectral resolution can resolve dry layers in the troposphere whose width can be as small as $\approx 1.5-2 \mathrm{~km}$. The comparison with GPS tomography shows that IASI retrieval accuracy is within $10 \%$ in the lower troposphere and in layers of $2 \mathrm{~km}$ width. A good accuracy is also confirmed in terms of precipitable water.

An inter-comparison between LATMOS and DIFA has shown to be internally consistent despite the two schemes relying on quite diverse background, retrieval strategy and number of IASI observations. Apparently, the superiority of DIFA in resolving structures in the lower troposphere is largely due to a better background. Finally, we have also shown that IASI can have the capability to detect overshooting convection, an issue which is left for further investigation.

\section{Acknowledgments}

T. Deleporte would like to thank CNES/TOSCA for the financial support. IASI has been developed and built under the responsibility of the Centre National d'Etudes Spatiales (CNES, France). It is flown onboard the Metop satellites as part of the EUMETSAT Polar System. The IASI L1 data are received through the EUMETCast near real time data distribution service.

\section{References}

Amato, U., G. Masiello, C. Serio, M. Viggiano, 2002: The $\sigma$-iasi code for the calculation of infrared atmospheric radiance and its derivatives. - Environ. Model. Software 17, 651-667. doi:10.1016/S1364-8152(02)00027-0.

Barret, B., S. Turquety, D. Hurtmans, C. ClerbauX, J. Hadji-Lazaro, I. Bey, M. Auvray, P.-F. COHEur, 2005a: Global carbon monoxide vertical distributions from spaceborne high-resolution ftir nadir measurements. Atmos. Chem. Phys. 5, 2901-2914.

Barret, B., D. Hurtmans, M.-R. Carleer, M. DE MAZIÈre, E. MAHIEU, P.-F. COHEUR, 2005b: Line narrowing effect on the retrieval of HF and HCL vertical profiles from ground-based FTIR measurements. - J. Quant. Spectros. Radia. Transfer 95, 499-519.

Bastin, S., C. Champollion, O. Bock, P. Drobinski, F. MASSON, 2005: On the use of GPS tomography to investigate water vapor variability during a mistral/sea breeze event in southeastern france. - Geophys. Res. Lett. 32, L05808. doi:10.1029/2004GL021907.

BAUER, H.-S., V. WUlfMEYER, T. SCHWitalla, F. Zus, M. GRZESCHIK, 2011: Operational assimilation of gps slant path delay measurements into the MM5 4DVAR system. Tellus A 63, 263-282.

Behrendt, A., V. Wulfmeyer, P. Di Girolamo, C. Kiemle, H.-S. BAuer, T. SCHABERL, D. Summa, D.N. Whiteman, B.B. Demoz, E.V. Browell, S. Ismail, R. FErrare, S. KoOI, G. EHret, J. WANG, 2007a: Intercomparison of water vapor data measured with lidar during ihop 2002, part 1: Airborne to ground-based lidar systems and comparisons with chilled-mirror hygrometer radiosondes. - J. Atmos. Ocean. Technol. 24, 3-21. doi:10.1175/ JTECH1924.1.

Behrendt, A., V. Wulfmeyer, C. Kiemle, G. Ehret, C. Flamant, T. Schaberl, H.-S. Bauer, S. KoOI, S. ISMAIL, R. FERrare, E.V. BROWELl, D.N. WhiteMAN, 2007b: Intercomparison of water vapor data measured with lidar during ihop 2002, part 2: Airborne to airborne systems. - J. Atmos. Ocean. Technol. 24, 22-39. doi:10.1175/JTECH1925.1.

BeHREndt, A., V. WulfMEYER, A. Riede, G. WAGNer, S. PAL, H. BAUER, M. RADlaCh, F. SPÄTH, 2009: 3Dimensional observations of atmospheric humidity with a scanning differential absorption lidar. - In R.H. PICARD, K. SCHÄFER, A. COMERON et al. (Eds.): Remote Sensing of Clouds and the Atmosphere XIV, volume 7475. - SPIE Conference Proceeding, doi:10.1117/12.835143.

Behrendt, A., S. PAL, H. BAuer, V. Wulfmeyer, 2011a: cops_suph_wvdial: Profiles of absolute humidity and backscatter signals at $820 \mathrm{~nm}$ measured with the water vapor differential absorption lidar of University of Hohenheim (UHOH DIAL) during COPS 2007. - World Data Climate Center. doi:10.1594/WDCC/cops_suph_wvdial.

BeHrendt, A., S. PAL, F. AOshima, M. Bender, A. Blyth, U. Corsmeier, J. Cuesta, G. Dick, M. Dorninger, C. Flamant, P. Di Girolamo, T. Gorgas, 
Y. Huang, N. Kalthoff, S. Khodavar, H. ManNSTEIN, K. TRÄUMNER, A. WIESER, V. WULFMEYER, 2011b: Observation of convection initiation processes with a suite of state-of-the-art research instruments during COPS IOP8b. - Quart. J. Roy. Meteor. Soc. 137, 81-100. doi:10.1002/qj.758.

Bennett, L.J., A.M. Blyth, R.R. Burton, A.M. Gadian, T.M. WeCKWERTh, A. BehrendT, P. Di Girolamo, M. DORNINGER, S.-J. LOCK, V.H. SMITH, S.D. MoBBS, 2011: Initiation of convection over the black forest mountains during COPS IOP15A. - Quart. J. Roy. Meteor. Soc. 137, 176-189. doi:10.1002/qj.760.

Bevis, M., S. Businger, T. Herring, C. Rocken, R.A. ANTHES, R.H. WARE, 1992: GPS meteorology: Remote sensing of the atmospheric water vapor using the global positioning system. - J. Geophys. Res. 97, 15787-15801.

Bhawar, R., P. Di Girolamo, D. Summa, C. Flamant, D. Althausen, A. Behrendt, C. Kiemle, P. Bosser, M. CACCIANI, C. Champollion, T. DI IORIO, R. EngelmanN, C. Herold, D. Müller, S. PAl, M. WIRTH, V. WULFMEYER, 2011: The water vapour intercomparison effort in the framework of the convective and orographically-induced precipitation study: airborneto-ground-based and airborne-to-airborne lidar systems. - Quart. J. Roy. Meteor. Soc. 137, 325-348.

Bielli, S., M. GrzeschiK, E. Richard, C. Flamant, C. Champollion, C. Kiemle, M. Dorninger, P. BrousSEAU, 2011: Assimilation of water-vapour airborne lidar observations: impact study on the COPS precipitation forecasts. - Quart. J. Roy. Meteor. Soc. 138, 1652-1667. doi:10.1002/qj.1864.

BOEHM, J., H. SCHUH, 2004: Vienna mapping functions in VLBI analyses. - Geophys. Res. Lett. 31, L01603. doi:10.1029/2003GL018984.

Bosser, P., O. Bock, C. Thomas, J. Pelon, 2007: Study of the statistics of water vapor mixing ratio determined from raman lidar measurements. - Appl. Optics 46, 8170-8180. doi:10.1364/AO.46.008170.

Bosser, P., O. Bock, C. Thomas, J. Pelon, P. Willis, 2010: A case study of using raman lidar measurements in high-accuracy gps applications. - J. Geodesy 84, 251265.

Bruneau, D., P. Quaglia, C. Flamant, M. MEISSONNIER, J. PELON, 2001a: Airborne Lidar LEANDRE II for watervapor profiling in the Troposphere. I. system description. Appl. Optics 40, 3450-3461.

Bruneau, D., P. Quaglia, C. Flamant, J. Pelon, 2001b: Airborne Lidar LEANDRE II for water-vapor profiling in the Troposphere. II. first results. - Appl. Optics 40, 3462-3475.

Calbet, X., R. Kivi, S. TJemkes, F. Montagner, R. STUHLMANN, 2011: Matching radiative transfer models and radiosonde data from the EPS/Metop Sodankyla campaign to IASI measurements. - Atmos. Meas. Tech. 4, 1177-1189. doi:10.5194/amt-4-1177-2011.

CARISsimo, A., I. DE FEIS, C. SERIO, 2005: The physical retrieval methodology for IASI: the $\delta$-iasi code. - Environ. Model. Software 20, 1111-1126.
Champollion, C., F. Masson, M.-N. Bouin, A. WalPERSDORF, E. DOERFLINGER, O. BOCK, van J. BAELEN, 2005: GPS water vapor tomography: Preliminary results from the escompte field experiment. - Atmos. Res. 74, 253-274.

Champollion, C., C. Flamant, O. Bock, F. Masson, D.D. TURNER, T. WECKWERTH, 2009: Mesoscale GPS tomography applied to the 12 June 2002 convective initiation event of IHOP 2002. - Quart. J. Roy. Meteor. Soc. 135, 645-662.

Chevallier, F., 2001: Sampled database of 60-level atmospheric profiles from the ECMWF analyses, research report, no. 4. - Technical report, EUMETSAT/ECMWF, http://research.metoffice.gov.uk/research/interproj/nwpsaf/ $\mathrm{rtm} /$ profiles_60L.pdf.

ChÉDin, A., M.T. Chahine, N.A.E. ScotT, 1993: High spectral resolution infrared remote sensing for earth's weather and climate studies, volume 19. - NATO ASI Series.

Clough, S.A., M.W. Shephard, E.J. MLAWER, J.S. Delamere, M.J. IACONO, K. CADY-PEREIRA, S. BOUKABARA, P.D. BROWN, 2005: Atmospheric radiative transfer modeling: a summary of the aer codes. - J. Quant. Spectros. Radiative Transfer 91, 233-244.

Coheur, P.-F., B. BArRet, S. Turquety, D. Hurtmans, J. Hadji-Lazaro, C. ClerbauX, 2005: Retrieval and characterization of ozone vertical profiles from a thermal infrared nadir sounder. - J. Geophys. Res. 110, D24303. doi:10.1029/2005JD005845.

Connor, B.J., D.E. Siskind, J.J. Tsou, A. PARrish, E.E. REMSBERG, 1994: Ground-based microwave observations of ozone in the upper stratosphere and mesosphere. - J. Geophys. Res. 99, 16757-16770.

CORSMEIER, U., N. KAlthoff, C. BARTHLOtT, F. AOShima, A. Behrendt, P. Di Girolamo, M. Dorninger, J. HANDWERKER, C. KOTTMEIER, H. MAHLKE, S.D. MOBbS, E.G. NORTON, J. WICKERT, V. WUlfMEYER, 2011: Processes driving deep convection over complex terrain: a multi-scale analysis of observations from cops IOP 9c. - Quart. J. Roy. Meteor. Soc. 137, 137-155. doi:10.1002/qj.754.

Di Girolamo, P., R. Marchese, D.N. Whiteman, B.B. DEMOZ, 2004: Rotational raman lidar measurements of atmospheric temperature in the UV. - Geophys. Res. Lett. 31, L01106. doi:10.1029/2003GL018342.

Di Girolamo, P., A. Behrendt, V. Wulfmeyer, 2006: Pure rotational raman lidar measurements of atmospheric temperature and extinction from space: performance simulations. - Appl. Optics 45, 2474-2494.

Di Girolamo, P., A. Behrendt, C. KiemLe, V. Wulfmeyer, H. BAuER, A. Summa, D. Dörnbrack, G. EHret, 2008: Simulation of satellite water vapour lidar measurements: Performance assessment under real atmospheric conditions. - Remote Sens. Environ. 112, 1552-1568.

Di Girolamo, P., D. Summa, R. Ferretti, 2009a: Rotational raman lidar measurements for the characterization of stratosphere-troposphere exchange mechanisms. - J. Atmos. Oceanic Technol. 26, 1742-1762. 
Di Girolamo, P., D. Summa, R.F. Lin, T. Maestri, R. RIZZI, G. MASIELlO, 2009b: UV raman lidar measurements of relative humidity for the characterization of cirrus cloud microphysical properties. - Atmos. Chem. Phys. 9, 8799-8811.

Di Girolamo, P., D. Summa, T. Di Iorio, E.G. Norton, G. PETERS, Y. DUfOURNET, 2012a: Lidar and radar measurements of the melting layer in the frame of the convective and orographically-induced precipitation study: observations of dark and bright band phenomena. - Atmos. Chem. Phys. 12, 4143-4157. doi:10.5194/acp-12-4143-2012.

Di Girolamo, P., D. Summa, R. Bhawar, T. Di IORIO, M. CACCiAni, I. Veselovskit, O. DuboviK, A. Kolgotin, 2012b: Raman lidar observations of a saharan dust outbreak event: Characterization of the dust optical properties and determination of particle size and microphysical parameters. - Atmos. Environ. 50, 66-78. doi:10.1016/j.atmosenv.2011.12.061.

FlORES, A., G. RUFFINI, A. RIUS, 2000: 4D tropospheric tomography using GPS slant wet delays. - Annales Geophysicae 18, 223-234.

Grieco, G., A. Luchetta, G. Masiello, C. Serio, M. VIGGIANO, 2005: IMG O3 retrieval and comparison with toms/adeos columnar ozone: an analysis based on tropical soundings. - J. Quant. Spectros. Radia. Transfer 95, 331348. doi:10.1016/j.jqsrt.2004.11.016.

Grieco, G., G. Masiello, M. Matricardi, C. Serio, D. SUMMA, V. CUOMO, 2007: Demonstration and validation of the $\varphi$-IASI inversion scheme with NAST-I data. - Quart. J. Roy. Meteor. Soc. 133, 217-232. doi:10.1002/qj.162.

GRIECO, G., G. MASIELlO, C. SERIO, 2010: Interferometric VS spectral IASI radiances: Effective data-reduction approaches for the satellite sounding of atmospheric thermodynamical parameters. - Remote. Sens. 2, 23232346. doi: $10.3390 / \mathrm{rs} 2102323$.

GÉrard, E., D.G.H. TAN, L. GARAND, V. Wulfmeyer, G. EHRET, P. Di GIROLAMO, 2004: Major advances foreseen in humidity profiling from the water vapour lidar experiment in space (Wales). - Bull. Amer. Meteor. Soc. 85, 237-251.

Herbin, H., D. Hurtmans, C. Clerbaux, L. Clarisse, P.-F. COHEUR, 2009: $\mathrm{H}_{2}{ }^{16} \mathrm{O}$ and HDO measurements with IASi/MetOp. - Atmos. Chem. Phys. 9, 9433-9447.

Hilton, F., R. Armante, T. August, C. Barnet, A. Bouchard, C. CAmy-Peyret, V. CaPelle, L. Clarisse, C. Clerbaux, P.-F. Coheur, A. Collard, C. Crevoisier, G. Dufour, D. EdWards, F. FAiJan, N. Fourrié, A. GAMBACORTA, M. GOLDBERG, V. GUIDARD, D. HURTMANS, S. ILLINGWORTH, N. JACQUINET-HUSSON, T. Kerzenmacher, D. KlaEs, L. LaVAnANT, G. Masiello, M. Matricardi, A. McNally, S. NeWman, E. Pavelin, S. Payan, E. PÉquignot, S. Peyridieu, T. Phulpin, J. Remedios, P. Schlüssel, C. SERIO, L. Strow, C. Stubenrauch, J. TAYlor, D. Tobin, W. WOLF, D. ZHOU, 2012: Hyperspectral earth observation from IASI: four years of accomplishments. - Bull. Amer. Meteor. Soc. 93, 347-370. doi:10.1175/BAMS-D-1100027.1.
Kiemle, C., M. Wirth, A. FiX, R.S.U. Corsmeier, P. DI GIROLAMO, 2011: Latent heat flux measurements over complex terrain by airborne water vapour and wind lidars. - Quart. J. Roy. Meteor. Soc. 137, 190-203. doi:10.1002/ qj. 757.

KING, R.W., Y. BocK, 2009: Documentation for the GAMIT GPS analysis software, release 10.4. - Department of Earth, Atmospheric and Planetary Sciences, Massachusetts Institute of Technology, Cambridge, and Scripps Institution of Oceanography, University of California at San Diego.

Lacour, J.-L., C. Risi, L. Clarisse, S. Bony, D. Hurtmans, C. ClerbauX, P.-F. Coheur, 2012: Midtropospheric $\delta$ D observations from IASI/MetOp at high spatial and temporal resolution. - Atmos. Chem. Physics 12, 10817-10832.

Maestri, T., P. Di Girolamo, D. Summa, R. RizZi, 2010: Synergistic use of a ground based raman lidar and the NAST-I airborne spectrometer in clear and cloudy sky conditions - eaquate, italy 2004. - Atmos. Res. 97, 157-169.

Masiello, G., C. Serio, 2013: Simultaneous physical retrieval of surface emissivity spectrum and atmospheric parameters from infrared atmospheric sounder interferometer spectral radiances. - Appl. Optics 52, 2428-2446. doi:10.1364/AO.52.002428.

MAsiello, G., M. MATriCARdi, R. RizZi, C. SERIO, 2002a: Homomorphism between cloudy and clear spectral radiance in the 800-900-cm-1 atmospheric window region. Appl. Optics 41, 965-973. doi:10.1364/AO.41.000965.

Masiello, G., M. MatriCARDI, R. RizZI, C. SERIO, 2002b: Homomorphism between cloudy and clear spectral radiance in the 800-900-cm-1 atmospheric window region. Appl. Optics 41, 965-973. doi:10.1364/AO.41.000965.

MASiello, G., C. Serio, H. ShimodA, 2003: Qualifying img tropical spectra for clear sky. - J. Quant. Spectros. Radia. Transfer 77, 131-148. doi:10.1016/S00224073(02), 00083-3.

MAsiello, G., C. Serio, V. CuOMO, 2004: Exploiting quartz spectral signature for the detection of cloud-affected satellite infrared observations over african desert areas. Appl. Optics 43, 2305-2315. doi:10.1364/AO.43.002305.

Masiello, G., C. Serio, A. Carissimo, G. Grieco, M. MATRICARDI, 2009: Application of $\varphi$-IASI to IASI: retrieval products evaluation and radiative transfer consistency. - Atmos. Chem. Phys. 9, 8771-8783. doi:10.5194/ acp-9-8771-2009.

MASIELlo, G., C. SERIO, P. ANTONELLI, 2012: Inversion for atmospheric thermodynamical parameters of IASI data in the principal components space. - Quart. J. Roy. Meteor. Soc. 138, 103-117. doi:10.1002/qj.909.

NASH, J., T. OAKLeY, H. VÖMEL, L. WeI, 2010: WMO intercomparison of high quality radiosonde systems. Technical report, WMO, http://www.wmo.int/pages/prog/ www/IMOP/publications/ IOM-107_Yangjiang/IOM107 Yangjiang.zip.

Niell, A.E., A.J. Coster, F.S. Solheim, V.B. Mendes, P.C. TOOR, R.B. LANGLEY, C.A. UPHAM, 2001: 
Comparison of measurements of atmospheric wet delay by radiosonde, water vapor radiometer, GPS, and VLBI. - J. Atmos. Ocean. Technol. 18, 830-850.

Pougatchev, N., T. August, X. Calbet, T. Hultberg, O. OdulEye, P. SchlüsSEl, B. STILlER, K. St. GERMAIN, G. BINGHAM, 2009: IASI temperature and water vapor retrievals - error assessment and validation. - Atmos. Chem. Phys. 9, 6453-6458.

REVErCOMB, H.E., D.D. TURner, D.C. TOBIN, R.O. Knuteson, W.F. Feltz, J. BARnard, J. BösenberG, S. Clough, D. CoOK, R. Ferrare, J. Goldsmith, S. Gutman, R. Halthore, B. Lesht, J. Liljegren, H. LinNé, J. Michalsky, V. MORRIS, W. PORCH, S. Richardson, B. Schmid, M. Splitt, T. VAN Hove, E. Westwater, D. Whiteman, 2003: The Arm Program's Water Vapor Intensive Observation Periods. - Bull. Amer. Meteor. Soc. 84, 217-236.

Richard, E., M. GrzeschiK, S. Bielli, C. Flamant, C. Champollion, C. KIEMLE, 2010: Assimilation of airborne lidar water vapor observations during COPS. Proceedings of 14th AMS Conference on Mountain Meteorology 9, 8771-8783.

RODGERS, C.D., 1976: Retrieval of atmospheric temperature and composition from remote measurements of thermal radiation. - Rev. Geophys. 14, 609-624.

RodGERS, C.D., 2000: Inverse Methods for Atmospheric Soudings: Theory and Practice. - World Scientific Pub Co, $240 \mathrm{pp}$.

Rothman, L.S., I.E. GORdON, A. BARBe, D.C. BENNER, P.F. BERNATH, M. BIRK, V. BOUdON, L.R. BROWN, A. Campargue, J.-P. Champion, K. Chance, L.H. Coudert, V. DANA, V.M. DEVI, S. FAlly, J.-M. Flaud, R.R. GAMACHE, A. GOLDMAN, D. JACQUEMART, I. KLEINER, N. LACOME, W.J. LAFFERTY, J.-Y. MANDIN, S.T. Massie, S.N. MikhailenKo, C.E. Miller, N. MoAzZEN-Ahmadi, O.V. NAUMENKO, A.V. Nikitin, J. Orphal, V.I. Perevalov, A. Perrin, A. Predoi-Cross, C.P. Rinsland, M. Rotger, M. ŠIMEČKOVÁ, M.A.H. SMith, K. Sung, S.A. TASHKUn, J. TENNYSON, R.A. Toth, A.C. VANDAEle, J. VANDER AuwERA, 2009: The HITRAN 2008 molecular spectroscopic database. - J. Quant. Spectros. Radia. Transfer 110, 533-572. doi:10.1016/j.jqsrt.2009.02.013.

SAASTAMOINEN, J., 1972a: Contributions to the theory of atmospheric refraction. - Bulletin Géodésique 105, 279298.

SAASTAMOINEN, J., 1972b: Introduction to practical computation of astronomical refraction. - Bulletin Géodésique 106, 383-397.

SAASTAMOINEN, J., 1973: Contributions to the theory of atmospheric refraction. - Bulletin Géodésique 107, 13-34.

SCHNEIDER, M., F. HASE, 2011: Optimal estimation of tropospheric $\mathrm{H} 2 \mathrm{O}$ and $\mathrm{dD}$ with IASI/METOP. - Atmos. Chem. Phys. 11, doi:10.5194/acp-11-11207-2011.

SeEmann, S.W., E.E. Borbas, R.O. Knuteson, G.R. STEPHENSON, H.-L. HuANG, 2008: Development of a Global Infrared Land Surface Emissivity Database for Application to Clear Sky Sounding Retrievals from
Multispectral Satellite Radiance Measurements. - J. Appl. Meteor. Climatol. 47, 108-123. doi:10.1175/2007JAMC 1590.1.

SERIO, C., A.M. LubranO, F. Romano, H. Shimoda, 2000: Cloud detection over sea surface by use of autocorrelation functions of upwelling infrared spectra in the 800-900-cm ${ }^{-1}$ window region. - Appl. Optics 39, 35653572. doi:10.1364/AO.39.003565.

SERIO, C., G. MASIELlO, G. GRIECO, 2009: Environmental Modelling: New Research, (Finley, P.N. ed.), chapter EOF Expression Analytical Model with Applications to the Retrieval of Atmospheric Temperature and Gas Constituents Concentrations from High Spectral Resolution Infrared Observations. - Nova Science Publishers, Inc, Hauppauge, NY, 51-88.

TAYlOR, J.P., W.L. SMith, V. CUOMO, A.M. LARAR, D.K. Zhou, C. Serio, T. Maestri, R. Rizzi, S. NeWman, P. Antonelli, S. Mango, P. Di Girolamo, F. Esposito, G. Grieco, D. Summa, R. Restieri, G. MAsiello, F. Romano, G. Pappalardo, G. Pavese, L. Mona, A. AMODEO, G. PISANI, 2008: Eaquate - an international experiment for hyper-spectral atmospheric sounding validation. - Bull. Amer. Meteor. Soc. 89, 203-218.

TETENS, O., 1930: Ueber einige meteorologische Begriffe. Z. Geophys. 6, 297-309.

Turner, D.D., R.A. Ferrare, L.A.H. Brasseur, W.F. FELTZ, T.P. TOOMAN, 2002: Automated Retrievals of Water Vapor and Aerosol Profiles from an Operational Raman Lidar. - J. Atmos. Ocean. Technol. 19, 37-50.

WAGNer, G., V. WULFMEYER, A. BEHRENDT, 2011: Detailed performance modeling of a pulsed high-power single-frequency ti:sapphire laser. - Appl. Optics 50, 5921-5937. doi:10.1364/AO.50.005921.

WAGNer, G., A. Behrendt, V. WulfMeyer, F. SpÄTH, M. SCHILLER, 2013: High-power Ti:sapphire laser at $820 \mathrm{~nm}$ for scanning ground-based water-vapor differential absorption lidar. - Appl. Optics 52, 2454, doi:10.1364/ AO.52.002454.

WANG, K., Z. WAN, P. WANG, M. Sparrow, J. LiU, X. ZHOU, S. HAGINOYA, 2005: Estimation of surface long wave radiation and broadband emissivity using moderate resolution imaging spectroradiometer (modis) land surface temperature/emissivity products. - J. Geophys. Res. 110, D11109. doi:10.1029/2004JD005566.

WHITEMAN, D.N., 2003: Examination of the traditional raman lidar technique. I: Evaluating the temperaturedependent lidar equations. - Appl. Optics 42, 2571-2592. WulfMEYER, V., A. BEHRENDT, 2007: COPS field report v2.1, with contribution of G. Adrian, D. Althausen, F. Aoshima, J. van Baelen, C. Barthlott, H.-S. Bauer, A. Blyth, C. Brandau, U. Corsmeier, G. Craig, S. Crewell, G. Dick, M. Dorninger, Y. Dufournet, G. Ehret, R. Engelmann, C. Flamant, T. Foken, C. Hauck, P. Di Girolamo, H. Graß1, M. Grzeschik, J. Handwerker, M. Hagen, R. M. Hardesty, C. Hauck, W. Junkermann, N. Kalthoff, C. Kiemle, C. Kottmeier, L. Krauss, C. Long, J. Lelieveld, F. Madonna, M. Miller, S. Mobbs, B. Neininger, S. Pal, G. Peters, M. Radlach, E. Richard, M. Rotach, H. 
Russchenberg, P. Schlüssel, U. Schumann, C. Simmer, R. Steinacker, D. Turner, S. Vogt, H. Volkert, T. Weckwerth, H. Wernli, A. Wieser, C. Wunraum. - COPS, https://www.unihohenheim.de/spp-iop/documents/COPSFieldReport2.pdf.

WulfMEYER, V., J. BÖSENBERG, 1996: Single-mode operation of an injection-seeded alexandrite ring laser for application in water-vapor and temperature differential absorption lidar. - Optics Letters 21, 1150-1152.

WulfMEYER, V., J. BÖSENBERG, 1998: Ground-based differential absorption lidar for water-vapor profiling: Assessment of accuracy, resolution, and meteorological applications. - Appl. Optics 37, 3825-3844.

Wulfmeyer, V., H. BAuER, P. Di Girolamo, C. SERio, 2005: Comparison of active and passive water vapor remote sensing from space: An analysis based on the simulated performance of IASI and space borne differential absorption lidar. - Remote Sens. Environ. 95, 211230 .

Wulfmeyer, V., A. BeHrendt, H.-S. BAuer, C. KotTMEIER, U. Corsmeier, A. Blyth, G. Craig, U. SchumanN, M. Hagen, S. Crewell, P. Di Girolamo, C. Flamant, M. Miller, A. Montani, S. Mobbs, E. Richard, M.W. ROTACH, M. ARPAGAUS, H. RUSSCHENBERG, P. SCHLÜSSEL, M. KÖNIG, V. GÄRTNER, R. STEINACKER, M. DORNINGER, D.D. Turner, T. WeckWERTh, A. Hense, C. Simmer, 2008: The convective and orographically induced precipitation study. - Bull. Amer. Meteor. Soc. 89, 1477-1486.

Wulfmeyer, V., C. Flamant, A. Behrendt, A. Blyth, A. Brown, M. DORNINGER, A. ILLINGWORTH, P. MASCART,
A. Montani, T. Weckwerth, 2011a: Advances in the understanding of convective processes and precipitation over low-mountain regions through the convective and orographically-induced precipitation study (COPS). Quart. J. Roy. Meteor. Soc. 137, 1-2. doi:10.1002/qj.799. Wulfmeyer, V., A. BehrendT, C. KotTMEIER, U. Corsmeier, C. Barthlott, G.C. Craig, M. Hagen, D. Althausen, F. Aoshima, M. Arpagaus, H.-S. BAuer, L. Bennett, A. Blyth, C. Brandau, C. Champollion, S. Crewell, G. Dick, P. Di Girolamo, M. Dorninger, Y. Dufournet, R. EIgEnmann, R. Engelmann, C. Flamant, T. FoKen, T. Gorgas, M. GRZESCHIK, J. HANDWERKER, C. HAUCK, H. HÖLLER, W. Junkermann, N. Kalthoff, C. Kiemle, S. KlinK, M. KÖNIG, L. KRAUSS, C.N. LONG, F. MAdONNA, S. MobBS, B. Neininger, S. Pal, G. Peters, G. Pigeon, E. RichARD, M.W. ROTACH, H. RUSSCHENBERG, T. SCHWitAlla, V. SMith, R. STEINACKER, J. TRENTMANN, D.D. TURNER, van J. BAELEN, S. VOGT, H. VOLKERT, T. WECKWERTH, H. WERNLI, A. WIESER, M. WIRTH, 2011b: The convective and orographically-induced precipitation study (COPS): the scientific strategy, the field phase, and research highlights. - Quart. J. Roy. Meteor. Soc. 137, 3-30.

Yan, X., V. DucrocQ, G. Jaubert, P. Brousseau, P. Poli, C. Champollion, C. Flamant, K. Boniface, 2009: The benefit of gps zenith delay assimilation to high-resolution quantitative precipitation forecasts: A case-study from cops IOP 9. - Quart. J. Roy. Meteor. Soc. 135, 1788-1800. 